\title{
Mass Spectrometric Characterization of an Acid-Labile Adduct Formed with 2-Amino-1-methyl-6-phenylimidazo[4,5-b]pyridine and Albumin in Humans
}

\author{
Yi Wang ${ }^{\dagger, \|}$, Peter W. Villalta ${ }^{\dagger}$, Lijuan Peng $^{\ddagger}$, Karen Dingley§, Michael A. Malfatti§, K.W. \\ Turteltaub§, and Robert J. Turesky ${ }^{\star}, \dagger, \|$ \\ †Masonic Cancer Center, University of Minnesota, 2231 6th Street, Minneapolis, MN 55455, USA \\ "Department of Medicinal Chemistry, Cancer and Cardiovascular Research Building, University of \\ Minnesota, 2231 6th Street, Minneapolis, MN 55455, USA \\ ¥School of Food Science and Engineering, Wuhan Polytechnic University, ChangQing Garden, \\ Hankou, Wuhan 430023, P.R. China \\ §Biosciences and Biotechnology Division, Center for Accelerator Mass Spectrometry Lawrence \\ Livermore National Laboratory, Livermore 94550, CA
}

\section{Abstract}

2-Amino-1-methyl-6-phenylimidazo[4,5-b]pyridine (PhIP) is a carcinogenic heterocyclic aromatic amine formed during the high temperature cooking of meats. The cytochrome P450-mediated $\mathrm{N}$ hydroxylation of the exocyclic amine group of PhIP produces 2-hydroxyamino-1-methyl-6phenylimidazo[4,5- $b$ ] pyridine (HONH-PhIP), an electrophilic metabolite which forms adducts with DNA and proteins. Previous studies conducted by our laboratory showed that the reaction of $\mathrm{N}$-oxidized-PhIP metabolites with human albumin in vitro occurs primarily at the $\mathrm{Cys}^{34}$ residue, to produce an acid-labile linked sulfinamide adduct. Based on these findings, we developed a sensitive ultraperformance liquid chromatography-mass spectrometry (UPLC-MS) method to measure acid-labile albumin-PhIP adducts in humansvolunteers administered a dietary-relevant dose of ${ }^{14} \mathrm{C}$-labelled-PhIP (Dingley et al., Cancer Epidemiol. Biomarkers Prev. 8:507-512). Mild acid-treatment of albumin $\left(0.1 \mathrm{~N} \mathrm{HCl}, 37^{\circ} \mathrm{C}\right.$ for $\left.1 \mathrm{~h}\right)$ or proteolytic digestion with pronase $(50 \mathrm{mM}$ ammonium bicarbonate buffer $\mathrm{pH} 8.5$ at $37^{\circ} \mathrm{C}$ for $18 \mathrm{~h}$ ) released similar amounts of covalently bound $\mathrm{PhIP}$, which was characterized by multistage scanning $\left(\mathrm{MS}^{3}\right)$ and quantified by Orbitrap mass spectrometry. The amount of ${ }^{14} \mathrm{C}$-PhIP recovered by acid-treatment of albumin 24 hour following dosing accounted for 7.2 to $21.3 \%$ of the ${ }^{14} \mathrm{C}-\mathrm{PhIP}$ bound to albumin based on accelerator mass spectrometry measurements. 2-Amino-1-methyl-6-(5-hydroxy)phenylimidazo[4,5- $b$ ]pyridine (5-HO-PhIP), a hydrolysis product of the $\mathrm{Cys}^{34} \mathrm{~S}-\mathrm{N}$ linked sulfenamide adduct of PhIP, was not detected in either acid-treated or protease treated samples.

\footnotetext{
*Corresponding Author: Robert J. Turesky, Masonic Cancer Center and Department of Medicinal Chemistry, Cancer and Cardiology Research Building, University of Minnesota, 2231 6th Street, Minneapolis, MN 55455, USA. Tel.: +1 612-626-0141; fax: +1 612-624-3869.

Supporting Information

Reconstructed ion chromatograms of PhIP, $\left[{ }^{2} \mathrm{H}_{3} \mathrm{C}\right]-\mathrm{PhIP}$, and $\left[{ }^{14} \mathrm{C}\right]-\mathrm{PhIP}$ standards. Product ion spectra of $\left[{ }^{2} \mathrm{H}_{3} \mathrm{C}\right]-\mathrm{PhIP}$. Calibration curve of PhIP in plasma extract. Product ion spectra of $\left[{ }^{14} \mathrm{C}\right]-\mathrm{PhIP}$ and $\left[{ }^{2} \mathrm{H} 3 \mathrm{C}\right]-\mathrm{PhIP}$ recovered from human plasma. This material is available free of charge via the Internet at http://pubs.acs.org.
} 
These findings suggest that a portion of the PhIP bound to albumin in vivo probably occurs as an acid labile-sulfinamide adduct formed at the $\mathrm{Cys}^{34}$ residue.

\section{TOC image}

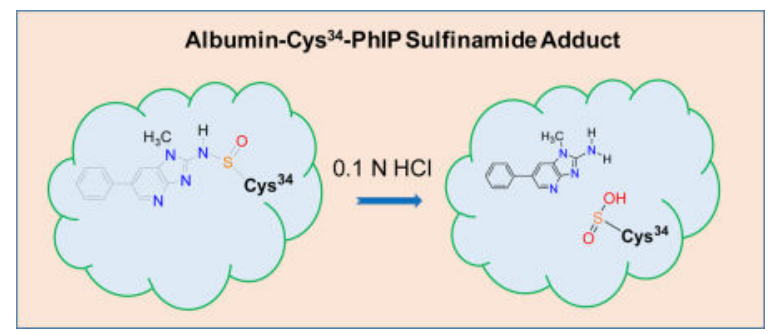

\section{Keywords}

Carcinogens; heterocyclic aromatic amines; serum albumin adducts; protein adducts

\section{INTRODUCTION}

Heterocyclic aromatic amines (HAA) are produced during the high-temperature cooking of meats, poultry, and fish, and some HAA are formed during the combustion of tobacco. ${ }^{1,2} 2$ Amino-1-methyl-6-phenylimidazo[4,5-b]pyridine (PhIP) is the most mass-abundant carcinogenic HAA formed in well done cooked red meats. ${ }^{1,3-5} \mathrm{PhIP}$ undergoes metabolic activation by cytochrome $\mathrm{P} 450$ (P450) to form 2-hydroxyamino-1-methyl-6phenylimidazo[4,5- $b]$ pyridine (HONH-PhIP), a genotoxic metabolite capable of reacting with DNA and proteins. ${ }^{6}$ The Working Group of the International Agency for Research on Cancer (IARC) recently classified red meat as probably carcinogenic to humans (Class 2A). The classification was based on a large body of epidemiological observations and mechanistic studies in humans and animal studies for the induction of colorectal cancer. 6,7 However, imprecise estimates of exposure and the lack of physicochemical evidence that mutagens formed in cooked meat induce DNA damage and mutations in target organs are critical missing links in the published literature and vital to performing a complete evaluation of the consumption of cooked meat and the risk of developing cancer. ${ }^{8}$

The biomonitoring of DNA adducts represents the most definitive biomarker to assess the biologically effective dose and genotoxic potential of a chemical. ${ }^{8,9}$ However, the measurement of DNA adducts is often limited because of the lack of tissue samples. Moreover, the repair of DNA adducts can diminish the levels of DNA adducts, and the measurement of DNA adducts remains a challenging endeavor even by the most sensitive of mass spectrometry (MS) instruments. ${ }^{6}$ The use of blood protein-carcinogen adducts is an alternative approach to biomonitor exposures to hazardous chemicals. ${ }^{10-12}$ Stable blood protein adducts do not undergo repair in vivo, and can accumulate during chronic exposure, and facilitate detection. In the case of PhIP, the same genotoxic metabolites that adduct to albumin are involved in DNA adduct formation. ${ }^{6}$ The albumin adduct levels are thus not only a measure of exposure but also of bioactivation of PhIP. 
Human albumin contains one reduced cysteine residue - the $\mathrm{Cys}^{34}$; a strong nucleophile at physiological $\mathrm{pH}(\mathrm{p} K \mathrm{a}=\sim 6.5)$ and scavenger of a variety of electrophiles. ${ }^{12,13}$ Early studies reported that the $\mathrm{Cys}^{34}$ residues of mouse or rat albumins reacted with the $\mathrm{N}$-oxidized metabolites of several HAA, including 2-amino-3-methylimidazo[4,5- $f$ quinoline (IQ), ${ }^{14}$ 2amino-3,8-dimethylimidazo[4,5- $f$ ]quinoxaline, ${ }^{15}$ and PhIP. ${ }^{16}$ In the case of IQ, the sulfinamide adduct formed with albumin in the rat, was isolated, digested with pronase and characterized by mass spectrometry. The ${ }^{1} \mathrm{H}-\mathrm{NMR}$ spectrum of the corresponding adduct formed in vitro with rat albumin was identified as a tripeptide $\mathrm{C} * \mathrm{PY}$ containing $N^{2}$ cysteinylsulfinyl-IQ. ${ }^{14} \mathrm{~A}$ model peptide containing sequence homology surrounding $\mathrm{Cys}^{34}$ of rat albumin was shown to react with the $\mathrm{N}$-acetoxy derivative of PhIP to form a sulfurnitrogen linked sulfenamide adduct, when characterized by ion trap MS. ${ }^{17}$ We employed ion trap MS to characterize human albumin adducts formed with N-oxidized metabolites of PhIP in vitro, followed by digestion of the modified protein with a mixture of trypsin and chymotrypsin. ${ }^{18-21}$ The primary adduct formed occurred at $\mathrm{Cys}^{34}$ and the peptides were identified as ${ }^{31} \mathrm{LQQC}^{*} \mathrm{PF}^{36}$ and the single missed-cleaved ${ }^{31} \mathrm{LQQC} * \mathrm{PFEDHVK}^{41}$ sulfinamide (C-[SO]-PhIP); the ${ }^{31} \mathrm{LQQC} * \mathrm{PFEDHVK}^{41}$ sulfonamide $\left(\mathrm{C}-\left[\mathrm{SO}_{2}\right]-\mathrm{PhIP}\right)$ was identified as a minor adduct. ${ }^{18,20}$ The hydrolysis of the albumin sulfinamide adduct of $\mathrm{PhIP}$ occurs under conditions sufficiently mild that the albumin is not degraded, ${ }^{14,20}$ and the released PhIP can be facilely separated from the macromolecular protein and assayed by sensitive MS based methods. The hydrolysis of albumin modified with $\mathrm{N}$-oxidized metabolites of PhIP, by pronase digestion or mild acid treatment, resulted in the recovery of $\mathrm{PhIP}$, which was principally derived from the sulfinamide (C-[SO]-PhIP) linked adduct. ${ }^{19,20}$ The ring-oxidized product 2-amino-1-methyl-6-(5-hydroxy)-phenylimidazo[4,5-b]pyridine (5-HO-PhIP) was also identified in the proteolytic digest of $N$-(acetyloxy)-2-amino-1methyl-6-phenylimidazo[4,5- $b$ ]pyridine ( $N$-acetoxy-PhIP) adducted adducted albumin, suggesting a sulfenamide adduct of PhIP had formed at the $\mathrm{Cys}^{34}$ of albumin (Scheme 1). ${ }^{19,21,22}$

Two studies used accelerator mass spectrometry (AMS) to measure ${ }^{14} \mathrm{C}-\mathrm{PhIP}$ blood protein adduct formation in humans. ${ }^{23,24}$ Both studies reported that PhIP bound poorly to hemoglobin, but levels approaching up to $\sim$ one percent of the dose bound to albumin. However, the structures of the adducts were not determined. The Airoldi laboratory developed gas chromatography-mass spectrometry and liquid chromatography-tandem mass spectrometry (LC-MS/MS) methods to measure acid-labile albumin adducts of PhIP in a cohort from Italy. ${ }^{25} \mathrm{PhIP}$ was detected in approximately 30 percent of the subjects. The mean level of albumin adducts of PhIP was significantly higher in meat consumers than in vegetarians (6.7 vs. $0.7 \mathrm{fmol} / \mathrm{mg}$ albumin). A more recent study conducted with a cohort from the United Kingdom did not reproduce the findings obtained from the Italian study. The authors concluded that acid-labile albumin adducts of PhIP or other HAA were not formed at levels sufficient to be detected by LC-MS/MS, and the proposed albumin sulfinamide adducts of HAA were unlikely to be viable biomarkers of HAA exposure. ${ }^{26}$

Based on our understanding of the chemistry of reactivity of N-oxidized metabolites of PhIP with human albumin in vitro, ${ }^{18-21}$ we sought to determine if acid-labile albumin adducts of PhIP are formed in humans. We used our characterized ${ }^{31} \mathrm{LQQC}^{*} \mathrm{PFEDHVK}^{41}$ sulfinamide (C-[SO]-PhIP) as a reference standard, and developed a sensitive UPLC-MS ${ }^{\mathrm{n}}$ method, 
employing high resolution accurate mass spectrometric measurement with Orbitrap MS, to characterize and measure the PhIP released from albumin purified from humans, following mild acid hydrolysis or proteolytic digestion. The samples were drawn from the Dingley study, where human volunteers were administered a single dose of $\left[{ }^{14} \mathrm{C}\right]-\mathrm{PhIP} .{ }^{24}$

\section{MATERIALS AND METHODS}

\section{Caution}

$\mathrm{PhIP}$ is a carcinogen and should be handled in a well-ventilated fume hood with the appropriate protective clothing.

\section{Chemicals and Materials}

PhIP, 2-amino-1-[ $\left[{ }^{2} \mathrm{H}_{3} \mathrm{C}\right]$-methyl-6-phenylimidazo[4,5-b]pyridine $\left(\left[{ }^{2} \mathrm{H}_{3} \mathrm{C}\right]-\mathrm{PhIP}, 99 \%\right.$ isotopic purity), and $\left[2-{ }^{14} \mathrm{C}\right]-\mathrm{PhIP}(10 \mathrm{mCi} / \mathrm{mmol})$ were purchased from Toronto Research Chemicals (Toronto, ON, Canada). Human serum albumin, pronase E, metachloroperoxybenzoic acid ( $m$-CPBA), hydrochloric acid $(\mathrm{HCl})$, and LC-MS grade formic acid were purchased from Sigma-Aldrich (St. Louis, MO). LC-MS grade solvents were purchased from Fisher Scientific (Pittsburgh, PA). All other chemicals were ACS grade, and purchased from Sigma-Aldrich unless stated. Isolute C18 solid-phase extraction (SPE) columns $(25 \mathrm{mg}$ ) were from Biotage (Charlotte, NC). SOLA HRP solid-phase extraction (SPE) columns (10 mg) were from Thermo Fisher Scientific (Rockford, IL). Amicon Ultra centrifugal filter units (10,000 mw cutoff) were from Millipore (Billerica, MA). Human plasma was purchased from Bioreclamation LLC (Hicksville, NY). Reference peptide LQQCPFEDHVK was purchased from New England Peptide (Gardner, MA). N-Oxidized derivatives of PhIP were synthesized as previously reported. ${ }^{20,21,27}$

\section{Human Protocol}

The details of this study were previously reported. ${ }^{24}$ Four volunteers were administered a dietary-equivalent of $\left[{ }^{14} \mathrm{C}\right]-\mathrm{PhIP}(70-84 \mu \mathrm{g}$, at a specific activity of $42 \mathrm{or} 56 \mathrm{mCi} / \mathrm{mmol})$ before colon cancer surgery. At various times up to $24 \mathrm{~h}$ after dosing, blood samples (30 $\mathrm{mL}$ ) were collected and separated into plasma, RBCs, and buffy coat by centrifugation, and immediately stored at $-80^{\circ} \mathrm{C}$. Plasma samples were stored on dry-ice and transported to the University of Minnesota for chemical analyses. For reference, the dose of PhIP that the subjects in this study received was approximately equivalent to eating $175 \mathrm{~g}$ of very welldone chicken, ${ }^{5}$ and the radioactive dose was $<1 \%$ of an individual's yearly exposure to background sources of radiation. The protocol for this study was approved by the human subject review boards at Lawrence Livermore National Laboratory, the University of Arkansas Medical School Hospital, and the J. L. McClellan Memorial Veterans Administration Medical Center in Little Rock, AR.

\section{AMS Analysis}

The carbon-14:carbon-13 ratios of albumin samples were assayed previously as described. ${ }^{24}$ For subjects 1 and 2, AMS analyses were performed and reported as the mean \pm standard deviation of four separate analyses. The AMS analyses for subjects 7 and 10 were derived from single values ( \pm standard deviation of the AMS measurement). 


\section{Syntheses of the PhIP Sulfinamide and Sulfonamide Adducts of LQQC*PFEDHVK}

The protocol for the synthesis of sulfinamide and sulfonamide adducts was described previously. ${ }^{28}$ Briefly, LQQCPFEDHVK ( $20 \mathrm{nmol}, 250 \mu \mathrm{L}$ in $10 \mathrm{mM}$ potassium phosphate buffer $\mathrm{pH}$ 8.5) was modified with 2-nitroso-1-methyl-6-phenylimidazo[4,5-b]pyridine (NOPhIP) $(60 \mathrm{nmol}, 50 \mu \mathrm{L}$ in $\mathrm{MeOH})$ at $5{ }^{\circ} \mathrm{C}$ for $1 \mathrm{~h}$. LQQC*PFEDHVK sulfinamide (C-[SO]$\mathrm{PhIP}$ ) was formed by adding $250 \mu \mathrm{L} 50 \mathrm{mM}$ potassium phosphate buffer $\mathrm{pH} 3.6$ to the reaction mixture, which agitated at $37^{\circ} \mathrm{C}$ for $1 \mathrm{~h}$. LQQC*PFEDHVK sulfonamide $\left(\mathrm{C}\right.$ - $\left[\mathrm{SO}_{2}\right]-$ $\mathrm{PhIP}$ ) was formed by oxidization of LQQC*PFEDHVK sulfinamide (C-[SO]-PhIP) by $m$ CPBA at a molar ratio of $1: 1$ at $37^{\circ} \mathrm{C}$ for $1 \mathrm{~h}$. LQQC*PFEDHVK sulfinamide (C-[SO]-

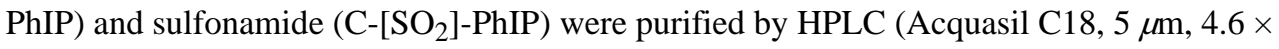
$250 \mathrm{~mm}$, Thermo Fisher) with a $25 \mathrm{~min}$ gradient from $100 \% \mathrm{~A}\left(5 \% \mathrm{ACN}\right.$ and $\left.95 \% \mathrm{H}_{2} \mathrm{O}\right)$ to $100 \% \mathrm{~B}(100 \% \mathrm{ACN})$, at a flow rate of $1 \mathrm{~mL} / \mathrm{min}$. The concentrations of LQQC $*$ PFEDHVK sulfinamide and sulfonamide were estimated by the UV absorbance of the PhIP chromophore at $315 \mathrm{~nm}$ (molar extinction coefficient, 22,220 M-1 $\mathrm{cm}^{-1}$ ). ${ }^{29}$ Structures of LQQC*PFEDHVK sulfinamide and sulfonamide were confirmed by sequencing and multistage scanning $\left(\mathrm{MS}^{\mathrm{n}}\right) \cdot{ }^{18,20}$

\section{Modification of Commercial Human Albumin with HONH-PhIP in vitro}

Mixed disulfides formed at $\mathrm{Cys}^{34}$ of albumin were reduced by treatment with $\beta$ mercaptoethanol. ${ }^{14}$ Albumin was modified with HONH-PhIP at a molar ratio of 1:3, at $37^{\circ} \mathrm{C}$ for $18 \mathrm{~h}$. Unbound HONH-PhIP and its decomposition products were removed by liquid extraction with $2 \times$ volume of ethyl acetate, twice. To fully convert the LQQC*PFEDHVK sulfinamide (C-[SO]-PhIP) to the LQQC*PFEDHVK sulfonamide (C$\left[\mathrm{SO}_{2}\right]-\mathrm{PhIP}$ ), the modified human albumin was oxidized by $m$-CPBA at a molar ratio of $1: 1$, at $37^{\circ} \mathrm{C}$ for $5 \mathrm{~h} .{ }^{21}$ The solution was subjected to a buffer exchange ( $450 \mu \mathrm{L}$ of $100 \mathrm{mM}$ potassium phosphate buffer, $\mathrm{pH} 7.4,2$-times) using centrifugal filters (10,000 mw cutoff).

\section{Purification of Albumin from Human Plasma}

Albumin was purified from human plasma samples using the Pierce Albumin Depletion Kit. Briefly, human plasma samples $(200 \mu \mathrm{L})$ were desalted using centrifugal filters $(10,000 \mathrm{mw}$ cutoff) with $25 \mathrm{mM}$ potassium phosphate buffer $\mathrm{pH}$ 7.4, twice. Desalted human plasma was applied to affinity resins (500 $\mu \mathrm{L} \mathrm{vol}$ ), which were equilibrated in $25 \mathrm{mM}$ potassium phosphate buffer $\mathrm{pH}$ 7.4. The resins bound with albumin were rinsed with $500 \mu \mathrm{L} 25 \mathrm{mM}$ potassium phosphate buffer, $\mathrm{pH} 7.4$ (three times), and eluted with $1 \mathrm{~mL}$ of $25 \mathrm{mM}$ potassium phosphate buffer, $\mathrm{pH} 7.4$ containing $1.5 \mathrm{M}$ potassium chloride. The elutes were desalted using centrifugal filters (10,000 mw cutoff).

\section{Acid Hydrolysis of Peptide Adducts of PhIP or Albumin-PhIP Adducts from Human Plasma}

The PhIP products unbound to albumin were removed by solvent extraction with $2 \times$ volume of ethyl acetate, twice. Thereafter, the synthetic peptides LQQC*PFEDHVK sulfinamide (C[SO]-PhIP) or sulfonamide (C-[ $\left[\mathrm{SO}_{2}\right]$-PhIP) (200 ng in $90 \mu \mathrm{L} \mathrm{H} \mathrm{H}_{2} \mathrm{O}$ ), or albumin purified from human plasma containing $\left[{ }^{14} \mathrm{C}\right]$-PhIP $(10 \mathrm{mg}$ albumin in $90 \mu \mathrm{L} 25 \mathrm{mM}$ potassium phosphate buffer, $\mathrm{pH}$ 7.4) was acidified with $10 \mu \mathrm{L} 1 \mathrm{~N} \mathrm{HCl}$. $\left[{ }^{2} \mathrm{H}_{3} \mathrm{C}\right]-\mathrm{PhIP}$ was spiked into the mixture as an internal standard at level of $500 \mathrm{fg}\left[{ }^{2} \mathrm{H}_{3} \mathrm{C}\right]-\mathrm{PhIP} / \mathrm{mg}$ albumin. The mixture was agitated 
at $37^{\circ} \mathrm{C}$ for $1 \mathrm{~h}$. Then, the mixture was made alkaline with $1 \mathrm{~N} \mathrm{NaOH}(15 \mu \mathrm{L})$, and the $\mathrm{PhIP}$ released from albumin was extracted by $\mathrm{CH}_{3} \mathrm{OH}$ or ethyl acetate. For the $\mathrm{CH}_{3} \mathrm{OH}$ extraction method, pre-chilled $\mathrm{CH}_{3} \mathrm{OH}\left(900 \mu \mathrm{L},-80^{\circ} \mathrm{C}\right)$ was added to the mixture to precipitate the proteins at $-20{ }^{\circ} \mathrm{C}$ for $2 \mathrm{~h}$. The solution was centrifuged at $18,000 \mathrm{~g}$ for $20 \mathrm{~min}$, and the supernatant was transferred to a $2 \mathrm{~mL}$ Eppendorf tube, vacuum centrifuged for $30 \mathrm{~min}$ to remove $\mathrm{CH}_{3} \mathrm{OH}$, and resuspended in $\mathrm{H}_{2} \mathrm{O}(1 \mathrm{~mL})$. For the ethyl acetate extraction method, ethyl acetate $(1 \mathrm{~mL})$ was added to the mixture. After vortexing, the upper layer containing the organic fraction was transferred to an Eppendorf tube, vacuum centrifuged to dryness, and resuspended in $\mathrm{H}_{2} \mathrm{O}(1 \mathrm{~mL})$. The mixture was applied to a SOLA HRP cartridge (10 $\mathrm{mg})$. The cartridge was rinsed with $10 \% \mathrm{CH}_{3} \mathrm{OH}(2 \mathrm{~mL})$, and PhIP was eluted with $\mathrm{CH}_{3} \mathrm{OH}$ $(1 \mathrm{~mL})$. The elute was vacuum centrifuged to dryness. The levels of adducts measured were the same for both clean-up methods (data not shown); however, the extraction with ethyl acetate provided cleaner chromatograms and was used for all in vivo studies.

\section{Proteolytic Digestion with Pronase E}

Peptide or protein adducts were digested with pronase $\mathrm{E}(1: 2 \mathrm{w} / \mathrm{w})$ in $50 \mathrm{mM}$ ammonium bicarbonate buffer $\mathrm{pH} 8.5$ at $37{ }^{\circ} \mathrm{C}$ for $18 \mathrm{~h}$. The mixture was applied to an Isolute $\mathrm{C} 18 \mathrm{SPE}$ column. Polar peptides or amino acids were removed with $10 \% \mathrm{CH}_{3} \mathrm{OH}(2 \mathrm{~mL})$ and adducts were eluted with $\mathrm{CH}_{3} \mathrm{OH}(1 \mathrm{~mL})$, followed by concentration to dryness by vacuum centrifugation.

\section{Stability of PhIP-Albumin Adducts in Human Plasma in vitro}

Human plasma containing $\left[{ }^{14} \mathrm{C}\right]-\mathrm{PhIP}(150 \mu \mathrm{L})$ was diluted with an equal volume of 100 $\mathrm{mM}$ potassium phosphate buffer ( $\mathrm{pH}$ 7.4) and incubated at $37^{\circ} \mathrm{C}$ for $0 \mathrm{~h}, 6 \mathrm{~h}, 1 \mathrm{~d}, 3 \mathrm{~d}$ or $7 \mathrm{~d}$. HONH-PhIP modified commercial human albumin ( $150 \mathrm{pmol})$ was added to $100 \mathrm{mM}$ potassium phosphate buffer $(\mathrm{pH} 7.4,1 \mathrm{~mL})$ or commercial human plasma $(1 \mathrm{~mL})$ and also incubated overtime. Procedures for albumin purification and ensuing acid hydrolysis of PhIP adducts are the same as those conditions reported above. The PhIP products unbound or released from albumin were removed by solvent extraction with $2 \times$ volume of ethyl acetate, twice, prior to acid hydrolysis of the remaining PhIP bound to albumin, followed by isolation of the released PhIP using the sample clean-up by SPE as described above.

\section{Measurement of PhIP and 5-HO-PhIP by Ultraperformance Liquid Chromatography- Electrospray lonization-Multistage Mass Spectrometry (UPLC-ESI/MS ${ }^{n}$ )}

The acid hydrolysis products of albumin PhIP adducts were assayed by UPLC-ESI/MS ${ }^{\mathrm{n}}$ employing a Dionex Ultimate 3000 LC and an Orbitrap Elite ${ }^{\mathrm{TM}}$ Hybrid Ion Trap-Orbitrap mass spectrometer (Thermo Fisher Scientific, San Jose, CA). Following SPE, the extracts were resuspended in 10\% DMSO:90\% $\mathrm{H}_{2} \mathrm{O}(25 \mu \mathrm{L})$, and $5 \mu \mathrm{L}$ was loaded on to a trapping column (Thermo Fisher Scientific Acclaim PepMap $100 \mathrm{C} 18,100 \mathrm{~A}^{\circ}$, particle size $5 \mu \mathrm{m}$, $300 \mu \mathrm{m} \times 5 \mathrm{~mm})$ with $99 \% \mathrm{~A}\left(1 \% \mathrm{ACN}, 0.01 \% \mathrm{HCO}_{2} \mathrm{H}\right)$ at a flow rate of $5 \mu \mathrm{L} / \mathrm{min}$ for 6 min. The products were back flushed onto a Michrom C18 column $(0.1 \times 150 \mathrm{~mm}, 3 \mu \mathrm{m}$ particle), resolved with a 25 min linear gradient from $99 \% \mathrm{~A}\left(1 \% \mathrm{CH}_{3} \mathrm{CN}, 0.01 \% \mathrm{HCO}_{2} \mathrm{H}\right.$ to $99 \% \mathrm{~B}\left(95 \% \mathrm{CH}_{3} \mathrm{CN}, 0.01 \% \mathrm{HCO}_{2} \mathrm{H}\right)$ at a flow rate of $1 \mu \mathrm{L} / \mathrm{min}$. Chromeleon 7.2 Chromatography Data System was used for the UPLC management. The Advance CaptiveSpray (Michrom Bioresource, Auburn, CA) was employed as the ion source and MS 
parameters were set as follows: capillary temperature, $270{ }^{\circ} \mathrm{C}$; ionization voltage, $2 \mathrm{kV}$ at positive ion mode; $1 \mu$ scan; maximum injection time, $100 \mathrm{~ms}$ for MS and $200 \mathrm{~ms}$ for $\mathrm{MS}^{\mathrm{n}}$; MS fragmentation used a normalized collision energy of $45 \%$; no auxiliary and sheath gases were used. Resolution was set as 60,000 at $\mathrm{m} / \mathrm{z} 400$ for selected ion monitoring (SIM), and 15,000 at $m / z 400$ for $\mathrm{MS}^{2}$ and $\mathrm{MS}^{3}$. The isolation width was set at $m / z 1$ for $\mathrm{MS}^{2}$ and $\mathrm{MS}^{3}$ scan modes, and the activation Q was set at 0.3. AGC (automated gain control) was set at 50,000 for Orbitrap (FT) $\mathrm{MS}^{2}$ and $\mathrm{MS}^{3}$. The Orbitrap was routinely calibrated in positive ion mode using Pierce LTQ Velos ESI Positive Ion Calibration Solution ( $2 \mu \mathrm{g} / \mathrm{mL}$ caffeine, 1 $\mu \mathrm{g} / \mathrm{mL}$ MRFA, $0.001 \%$ Ultramark 1621 and $0.00005 \%$ n-butylamine).

\section{Calibration Curve and Quantitation of PhIP}

Seven calibrant points $(0,50,100,250,500,1000,1250 \mathrm{fg} \mathrm{PhIP}$ or 5-HO-PhIP/mg albumin) were constructed using unlabeled $\mathrm{PhIP}$ and 5-HO-PhIP, which were added to the extract post-cleanup of acid-treated commercial albumin purified from plasma. $\left[{ }^{2} \mathrm{H}_{3} \mathrm{C}\right]-\mathrm{PhIP}$ and 5$\mathrm{HO}-\left[{ }^{2} \mathrm{H}_{3} \mathrm{C}\right]-\mathrm{PhIP}$ were added internal standards at a level of $500 \mathrm{fg} / \mathrm{mg}$ albumin. PhIP and $\left[{ }^{2} \mathrm{H}_{3} \mathrm{C}\right]-\mathrm{PhIP}$ were measured at the $\mathrm{MS}^{3}$ scan stage using product ions at $\mathrm{m} / \mathrm{z} 225.1$ or 228.1 $>210.1>168.0682$ and 183.0791 for PhIP, and $\left[{ }^{14} \mathrm{C}\right]-\mathrm{PhIP}$ was measured at $\mathrm{MS}^{3}$ scan stage using product ions at $\mathrm{m} / \mathrm{z} 227.1>212.1>168.0682,183.0791$ and 185.0823. 5-HO-PhIP, 5HO- $\left[{ }^{2} \mathrm{H}_{3} \mathrm{C}\right]-\mathrm{PhIP}$ and 5-HO- $\left[{ }^{14} \mathrm{C}\right]-\mathrm{PhIP}$ were measured at $\mathrm{MS}^{3}$ scan stage using product ions at $\mathrm{m} / \mathrm{z} 241.1>223.1>196.0867,208.0742 ; \mathrm{m} / \mathrm{z} 244.1>226.1>198.0902,210.0776$; and $\mathrm{m} / \mathrm{z} 243.1>225.1>199.1058,208.0742$, respectively. The calibration curves were generated with unlabeled PhIP and 5-HO-PhIP because the $\left[{ }^{14} \mathrm{C}\right]-\mathrm{PhIP}$ used for the human studies was largely carrier free ( 42 or $56 \mathrm{mCi} / \mathrm{mmol} ; 67$ or $90 \%$ labeled, respectively) and no longer available. Given that the signals of response of PhIP and $\left[{ }^{14} \mathrm{C}\right]-\mathrm{PhIP}(10 \mathrm{mCi} / \mathrm{mmol})$ are comparable, when the specific activity of the radioisotope is accounted for (Supporting information, Figs S-1A - S-1D), with little background noise in the $\mathrm{MS}^{3}$ scan stage chromatograms, we used PhIP as a substitute calibrant to estimate the acid-labile $\left[{ }^{14} \mathrm{C}\right]-\mathrm{PhIP}$ recovered from the albumin in vivo. This also minimized the contamination of radioactive PhIP in the mass spectrometer.

\section{Method Validation}

The assay was validated by the accuracy and within-day and between-day reproducibility using human albumin modified with HONH-PhIP at a known level of acid-labile adduct and diluted with commercial human plasma to arrive at a level of adduction of $675 \mathrm{fg} \mathrm{PhIP} / \mathrm{mg}$ albumin. This level of PhIP adduction to albumin was close to the average level $\left[{ }^{14} \mathrm{C}\right]-\mathrm{PhIP}$ bound to albumin reported in the AMS study of Dingley. ${ }^{24}$ The reproducibility studies were based on four independent measurements conducted on three different days. The accuracy and percent coefficient of variation $(\% \mathrm{CV})$ were used as criteria for the performance and reproducibility of the method.

\section{RESULTS}

The AMS studies conducted by Dingley reported that up to $\sim 0.2$ percent of the dose of $\left[{ }^{14} \mathrm{C}\right]-\mathrm{PhIP}$ administered to volunteers had bound to albumin; however, the structure(s) of the adduct(s) and stability towards acid (or base) were not reported. ${ }^{23,24}$ The levels of $\left[{ }^{14} \mathrm{C}\right]-$ 
PhIP bound to albumin were estimated, by AMS, at $\sim 500$ pg per g albumin $(\sim 1.5 \mathrm{PhIP}$ molecules bound per $10^{7}$ molecules of albumin), ${ }^{24}$ a level of modification far too low to directly measure the tryptic or chymotryptic peptide adduct. We sought to quantify the amount of $\left[{ }^{14} \mathrm{C}\right]-\mathrm{PhIP}$ bound to albumin in humans that could be recovered as $\left[{ }^{14} \mathrm{C}\right]-\mathrm{PhIP}$ or 5-HO- $\left[{ }^{14} \mathrm{C}\right]$-PhIP, following mild acid treatment, as would be expected for the PhIP sulfinamide or sulfenamide linkages (Scheme 1). We examined the stability of S-N linked adducts of the sulfinamide and sulfonamide adducts of with LQQC*PFEDHVK formed with HONH-PhIP following treatment with acid or pronase; however, the S-N linked adduct of the sulfenamide LQQC*PFEDHVK formed with $N$-acetoxy-PhIP was too unstable to isolate and characterize. Thereafter, we examined the recovery of acid-labile adducts of albumin modified in vitro with HONH-PhIP. Subsequently, we measured for $\left[{ }^{14} \mathrm{C}\right]-\mathrm{PhIP}$ and 5-HO$\left[{ }^{14} \mathrm{C}\right]$-PhIP hydrolysis product(s) from in vivo samples of purified albumin of volunteers of the Dingley study. ${ }^{24}$

\section{Mass Spectra of PhIP, $\left[{ }^{2} \mathrm{H}_{3} \mathrm{C}\right]-\mathrm{PhIP}$ and $\left[{ }^{14} \mathrm{C}\right]-\mathrm{PhIP}$ Standards}

The product ion spectra of the synthetic PhIP analogues were acquired online by UPLC/ $\mathrm{MS}^{\mathrm{n}}$. The ion chromatograms of protonated $\mathrm{PhIP}\left([\mathrm{M}+\mathrm{H}]^{+}\right.$at $\mathrm{m} / z$ 225.1135) and $\left[{ }^{14} \mathrm{C}\right]-\mathrm{PhIP}$ $\left([\mathrm{M}+\mathrm{H}]^{+}\right.$at $\left.m / z 227.1167\right)$ are shown in Fig. S-1. The ratios of peak areas of $\left[{ }^{14} \mathrm{C}\right]-\mathrm{PhIP}$ to $\mathrm{PhIP}$ by SIM and $\mathrm{MS}^{2}$ scan stage were $21.2 \pm 0.2 \%$ and $20.8 \pm 0.1 \%$, respectively (Figs S-1A - S-1D). Since the maximum specific activity available for carrier free molecule containing a single ${ }^{14} \mathrm{C}$ label is $62.4 \mathrm{mCi}$, high resolution accurate mass measurements of the $\left[{ }^{14} \mathrm{C}\right]-\mathrm{PhIP} /\left[{ }^{12} \mathrm{C}\right]-\mathrm{PhIP}$ ratio correspond to a specific activity of 13.2 and $13.0 \mathrm{mCi} / \mathrm{mmol}$ in SIM and $\mathrm{MS}^{2}$, respectively. The ratio of $\left[{ }^{14} \mathrm{C}\right]-\mathrm{PhIP}$ to $\mathrm{PhIP}$ at the $\mathrm{MS}^{3}$ scan stage was $19.1 \pm 0.4 \%$, or $12.1 \mathrm{mCi} / \mathrm{mmol}$ (Fig. S-1E and S-1F), which is consistent with the specific activity of $\left[{ }^{14} \mathrm{C}\right]-\mathrm{PhIP}$ reported by the vendor $(10 \mathrm{mCi} / \mathrm{mmol})$. There was no overlap of signals of the reconstructed ion chromatograms of $\left[{ }^{2} \mathrm{H}_{3} \mathrm{C}\right]$-PhIP with either $\mathrm{PhIP}$ or $\left[{ }^{14} \mathrm{C}\right]-$ $\mathrm{PhIP}$ at the $\mathrm{MS}^{2}$ and $\mathrm{MS}^{3}$ scan stages (Supporting information, Fig. S-2), when employing an isolation width of $1 \mathrm{~m} / z$ for $\mathrm{MS}^{2}$ and $\mathrm{MS}^{3}$, ensuring specificity of the transitions of PhIP analogues used for assay.

The product ion spectra of $\mathrm{PhIP}$ and $\left[{ }^{2} \mathrm{H}_{3} \mathrm{C}\right]$-PhIP obtained by collision induced dissociation (CID), (Fig 1) show a major product ion at $\mathrm{m} / \mathrm{z} 210.0897$ (observed vs. calculated 210.0900, $\Delta 1.4 \mathrm{ppm})$ as the base peak, and the $\left[{ }^{14} \mathrm{C}\right]-\mathrm{PhIP}$ undergoes CID to form a major fragment ion at $\mathrm{m} / \mathrm{z} 212.0928$ (observed vs. calculated 212.0932, $\Delta 1.9 \mathrm{ppm}$ ). These ions are attributed to the loss of $\mathrm{CH}_{3}{ }^{*}$ for PhIP and $\left[{ }^{14} \mathrm{C}\right]-\mathrm{PhIP}$, and the loss of $\left[{ }^{2} \mathrm{H}_{3} \mathrm{C}\right]^{\cdot}$ from the trideuterated internal standard (Figs 2A-2C), an observation in agreement with the literature. ${ }^{30} \mathrm{~A}$ minor product ion at $\mathrm{m} / \mathrm{z} 208.0874$ (observed vs. calculated 208.0875, $\Delta 0.5 \mathrm{ppm}$ ) for PhIP, $\mathrm{m} / \mathrm{z}$ 211.1065 (observed vs. calculated 211.1063, $\Delta 1.0 \mathrm{ppm}$ ) for $\left[{ }^{2} \mathrm{H}_{3} \mathrm{C}\right]-\mathrm{PhIP}$, or $\mathrm{m} / \mathrm{z} 210.0906$ (observed. vs. 210.0907, $\Delta 1.5 \mathrm{ppm}$ ) for $\left[{ }^{14} \mathrm{C}\right]-\mathrm{PhIP}$ results from the loss of $\mathrm{NH}_{3}$ (Figs 2A$2 \mathrm{C}$ ). Consecutive reaction monitoring of the radical cation at $\mathrm{m} / \mathrm{z} 210.09$ for PhIP and $\left[{ }^{2} \mathrm{H}_{3} \mathrm{C}\right]-\mathrm{PhIP}$ at the $\mathrm{MS}^{3}$ scan stage produces an ion at $\mathrm{m} / z 183.0787$ (observed vs. calculated 183.0791, $\Delta 2.2 \mathrm{ppm}$, loss of $\mathrm{HCN}$ ), $\mathrm{m} / z 168.0680$ (observed vs. calculated 168.0682, $\Delta 1.1$ ppm, loss of $\mathrm{H}_{2} \mathrm{CN}_{2}$ ), and $\mathrm{m} / z 167.0601$ (observed vs. calculated 167.0604, $\Delta 1.8 \mathrm{ppm}$, loss of $\mathrm{H}_{3} \mathrm{CN}_{2}{ }^{\circ}$ ) (Figs. 2D and 2E). Similarly, the product ion spectrum acquired for the $\mathrm{m} / \mathrm{z}$ 212.0932 of $\left[{ }^{14} \mathrm{C}\right]$-PhIP includes ions at $\mathrm{m} / \mathrm{z} 168.0680, \mathrm{~m} / \mathrm{z} 167.0600, \mathrm{~m} / \mathrm{z} 183.0786$ 
attributed to the loss of $\mathrm{H}^{14} \mathrm{CN}$, and an ion at $\mathrm{m} / \mathrm{z} 185.0823$ (observed vs. calculated 185.0823, $\Delta 0 \mathrm{ppm}$, loss of $\mathrm{HCN})$.

\section{Characterization of the Hydrolysis Products of LQQC*PFEDHVK Sulfinamide and Sulfonamide Adducts of PhIP}

The LQQC*PFEDHVK sulfinamide (C-[SO]-PhIP) undergoes hydrolysis under mild acidic $\mathrm{pH}$ conditions to produce $\mathrm{PhIP}$ and the cysteine sulfinic acid containing peptide. ${ }^{19,20}$ The LQQC*PFEDHVK sulfinamide ( $100 \mathrm{pg}=63 \mathrm{fmol})$ was subjected to acid hydrolysis in $0.1 \mathrm{~N}$ $\mathrm{HCl}$ for $1 \mathrm{~h}$ or pronase $\mathrm{E}$ digestion for $18 \mathrm{~h} .\left[{ }^{2} \mathrm{H}_{3} \mathrm{C}\right]-\mathrm{PhIP}(200 \mathrm{fg})$ was spiked as an internal standard prior to hydrolysis. PhIP was quantitatively recovered after acid hydrolysis, whereas $51 \mathrm{fmol}$ of PhIP was recovered from the LQQC*PFEDHVK sulfinamide following digestion with pronase $\mathrm{E}$ (Table 1). The lower recovery of PhIP by digestion of the modified albumin with pronase $\mathrm{E}$ was because the enzyme also produced some $\mathrm{C}^{*}$ and $\mathrm{C}^{*} \mathrm{PF}$ sulfinamide adducts. ${ }^{18,21}$

The LQQC*PFEDHVK sulfinamide (C-[SO]-PhIP) linkage can be oxidized to the acidstable sulfonamide linage ( $\mathrm{C}$-[ $\left.\left.\mathrm{SO}_{2}\right]-\mathrm{PhIP}\right)$, by treatment of the adducted peptide with $\mathrm{m}$ CPBA. ${ }^{20}$ We examined the stability of the sulfonamide linkage towards the same acid hydrolysis or proteolytic digestion conditions described above. PhIP was not recovered by either the acid or pronase treatment of LQQC*PFEDHVK sulfonamide (C-[ $\left.\left.\mathrm{SO}_{2}\right]-\mathrm{PhIP}\right)$. The digestion with pronase produced the tripeptide adduct $\mathrm{C} * \mathrm{PF}$ sulfonamide $\left(\mathrm{C}-\left[\mathrm{SO}_{2}\right]-\mathrm{PhIP}\right)$ (Table 1). These data demonstrate that the S-N linkage of the LQQC*PFEDHVK sulfinamide (C-[SO]-PhIP) is labile, and the adduct can be quantitatively hydrolyzed to $\mathrm{PhIP}$ by acid treatment or by pronase $\mathrm{E}$ digestion. In contrast, $\mathrm{S}-\mathrm{N}$ linkage of the LQQC*PFEDHVK sulfonamide $\left(\mathrm{C}-\left[\mathrm{SO}_{2}\right]-\mathrm{PhIP}\right)$ is stable and does not undergo hydrolysis to form PhIP.

\section{Acid Hydrolysis and Proteolytic Digestion of Commercial Human Albumin Modified with HONH-PhIP with or without Oxidation of $m$-CPBA}

LQQC*PF and LQQC*PFEDHVK sulfinamide (C-[SO]-PhIP) are major adducts identified in HONH-PhIP modified albumin following digestion with trypsin/chymotrypsin. ${ }^{28} \mathrm{~m}$ CPBA oxidizes the sulfenamide and sulfinamide-PhIP linked adducts to the stable sulfonamide (C-[SO $\left.\left.\mathrm{SO}_{2}\right]-\mathrm{PhIP}\right){ }^{28}$ Here we measured the recovery of PhIP from HONH-PhIPmodified human albumin without or with $m$-CPBA-pretreatment, followed by acid hydrolysis or proteolytic digestion with pronase $\mathrm{E}$.

To ensure that the PhIP recovered by hydrolysis was attributed to covalently bound $\mathrm{PhIP}$ albumin adducts, a liquid extraction was performed with $2 \times$ volume of ethyl acetate followed by sample cleanup with filtration, which effectively removes all unbound $\mathrm{PhIP}$ spiked into a solution of albumin. ${ }^{21}$ In the HONH-PhIP-modified albumin, $88 \pm 0.8$ and 64 \pm 14.6 (fmol PhIP/pmol albumin) PhIP was recovered after acid hydrolysis and proteolytic digestion with pronase $\mathrm{E}$, respectively (Table 2 ). By comparison, only $1.3 \pm 0.1$ and 3.3 \pm 0.3 (fmol PhIP/pmol albumin) was recovered from the $m$-CPBA oxidized albumin modified with HONH-PhIP (Table 2). These data recapitulate the findings observed with LQQC*PFEDHVK (C-[SO]-PhIP and C-[SO $\left.\left.{ }_{2}\right]-\mathrm{PhIP}\right)$ peptides: the sulfinamide adduct of 
$\mathrm{PhIP}$ in albumin is labile under acidic $\mathrm{pH}$ conditions, while sulfonamide adduct of $\mathrm{PhIP}$ is stable towards acid hydrolysis.

\section{Validation of the Method}

The levels of PhIP used for the calibration curve were chosen based on the level of $\left[{ }^{14} \mathrm{C}\right]-$ $\mathrm{PhIP}$ bound to albumin in vivo by AMS measurements. ${ }^{24}$ Seven calibrant points, ranging from 0, 50 up to $1250 \mathrm{fg} \mathrm{PhIP} / \mathrm{mg}$ albumin, were constructed for the calibration curve. $\left[{ }^{2} \mathrm{H}_{3} \mathrm{C}\right]-\mathrm{PhIP}$ was used as the internal standard and spiked at level of $500 \mathrm{fg} / \mathrm{mg}$ albumin. The linearity of calibration curve was confirmed by the slope $(s=1.03 \pm 0.0072)$ and linear regression value $\left(r^{2}=0.9997\right)$ (Supporting information, Fig. S-3). The $\left[{ }^{14} \mathrm{C}\right]-\mathrm{PhIP}$ of high specific activity used for the human study was no longer available, therefore, the calibration curves, limit of detection (LOD), and limit of quantification (LOQ) values were determined with unlabeled $\mathrm{PhIP}$. The ions at $\mathrm{m} / \mathrm{z} 168.0682$ and 183.0791 (and the ion at $\mathrm{m} / \mathrm{z} 185.0823$ for $\left.\left[{ }^{14} \mathrm{C}\right]-\mathrm{PhIP}\right)$ were used to determine the LOD and LOQ. Since no measurable ions $\mathrm{m} / \mathrm{z}$ $168.0682,183.0791$, and 185.0823 were observed in the unspiked sample at the $\mathrm{MS}^{3}$ scan stage using high-resolution Orbitrap (5 ppm mass tolerance), the LOD and LOQ were estimated by the formula $3.3 \sigma / s$ and $10 \sigma / s$, respectively ( $\sigma$ is the standard deviation of the slope ( $s$ ) of calibration curve). ${ }^{31,32}$ The LOD was estimated at $11 \mathrm{fg} \mathrm{PhIP} / \mathrm{mg}$ albumin, and the LOQ was estimated at $33 \mathrm{fg} \mathrm{PhIP} / \mathrm{mg}$ albumin. Approximately 12-13 scans were acquired across the full width of the peak of the calibrant spiked with the lowest amount of $\mathrm{PhIP}$ (50 fg PhIP/mg albumin). The spiking of commercial albumin extracts with $\left[{ }^{14} \mathrm{C}\right]-\mathrm{PhIP}$ $(10 \mathrm{mCi} / \mathrm{mmol})$ provided similar responses at the LOD and LOQ values (data not shown).

The amount of plasma available from treated volunteers was limited, thus we conducted the validation of the analytical method with commercial human plasma spiked with in vitro HONH-PhIP modified human albumin, which was diluted with commercial plasma containing non-detectable levels of PhIP modified albumin. The level of modification was $675 \mathrm{fg} \mathrm{PhIP} / \mathrm{mg}$ albumin, a level that is close to those levels of $\left[{ }^{14} \mathrm{C}\right]-\mathrm{PhIP}$ bound to albumin in vivo by AMS measurement. ${ }^{24}$ The method of validation was done with four independent measurements of HONH-PhIP modified albumin on three different days, following acid hydrolysis (Table 3 ). The accuracy was $94.7 \pm 2.5 \%$. The SD values for the within-day and between-day precision were $15 \%$ and $14 \%$, respectively. The reproducibility studies were further conducted with samples of albumin obtained from two volunteers dosed with $\left[{ }^{14} \mathrm{C}\right]-$ $\mathrm{PhIP}$ and based on three independent measurements on two different days (Table 4). The values of within-day and between-day precision $(\% \mathrm{CV})$ were 3.9 and $6.9 \%$ for volunteer 2 , and 6.6 and $7.2 \%$ for volunteer 10 , respectively.

\section{Acid Hydrolysis of Albumin and Measurement of $\left[{ }^{14} \mathrm{C}\right]-\mathrm{PhIP}$ Bound Albumin in Human Volunteers}

We employed the UPLC-ESI/MS ${ }^{3}$ method to measure $\left[{ }^{14} \mathrm{C}\right]$-PhIP recovered from hydrolysis of albumin purified from plasma of four volunteers. The specific activity of $\left[{ }^{14} \mathrm{C}\right]-\mathrm{PhIP}$ in capsules taken by human volunteers was 42 or $56 \mathrm{mCi} / \mathrm{mmol}(67 \%$ and $90 \%$ labeled, respectively). ${ }^{24}$ We monitored $\left[{ }^{14} \mathrm{C}\right]$-PhIP by SIM $(\mathrm{m} / z 220-230)$ following SPE of the acid hydrolyzed extract of albumin $\left(0.1 \mathrm{~N} \mathrm{HCl}, 37^{\circ} \mathrm{C}\right.$ for $1 \mathrm{~h}$ ) (Supporting information Fig. S4). The mass chromatograms at the SIM stage of (Fig. S4A, C, E) $\left[{ }^{14} \mathrm{C}\right]-\mathrm{PhIP}\left([\mathrm{M}+\mathrm{H}]^{+} \mathrm{m} / \mathrm{z}\right.$ 
227.1167), and (S4B, D, F) $\left[{ }^{2} \mathrm{H}_{3} \mathrm{C}\right]-\mathrm{PhIP}\left([\mathrm{M}+\mathrm{H}]^{+} \mathrm{m} / \mathrm{z} 228.1323\right.$ with mass tolerances set at 2,5 or $10 \mathrm{ppm}$ (Fig. S4) revealed high levels of isobaric interferences, particularly in the $\mathrm{m} / \mathrm{z}$ window for $\left[{ }^{14} \mathrm{C}\right]-\mathrm{PhIP}$, even at 60,000 mass resolution (Supporting information Fig. S4A, $\mathrm{C}, \mathrm{E})$. Thus, multistage scanning $\left(\mathrm{MS}^{2}\right.$ and $\mathrm{MS}^{3}$ ) was used to characterize and identify $\left[{ }^{14} \mathrm{C}\right]-\mathrm{PhIP}$ recovered from albumin. The reconstructed ion chromatograms of $\left[{ }^{14} \mathrm{C}\right]-\mathrm{PhIP}$ and $\left[{ }^{2} \mathrm{H}_{3} \mathrm{C}\right]-\mathrm{PhIP}$ at $\mathrm{MS}^{2}$ and $\mathrm{MS}^{3}$ stages from acid hydrolyzed albumin $\left(0.1 \mathrm{~N} \mathrm{HCl}, 37^{\circ} \mathrm{C}\right.$ for $1 \mathrm{~h}$ ) obtained from commercial plasma and plasma of a volunteer who was administered with $\left[{ }^{14} \mathrm{C}\right]-\mathrm{PhIP}$ are shown in Fig. 2 . Since the $\left[{ }^{14} \mathrm{C}\right]-\mathrm{PhIP}$ used in the study was largely carrier free, unlabeled PhIP was not monitored. The product ions of $\left[{ }^{14} \mathrm{C}\right]-\mathrm{PhIP}$ were not detected in the extract of commercial human plasma (Figs $2 \mathrm{~A}$ and $2 \mathrm{E}$ ), but the ions of $\left[{ }^{14} \mathrm{C}\right]-$ $\mathrm{PhIP}$ were readily detected in plasma from subjects at $24 \mathrm{~h}$ following dosing (Figs $2 \mathrm{~B}$ and $2 \mathrm{~F})$. Some isobaric interferences are seen in the reconstructed ion chromatogram of $\left[{ }^{14} \mathrm{C}\right]-$ $\mathrm{PhIP}$ at the $\mathrm{MS}^{2}$ scan stage (scan resolution 15,000) even when the mass tolerance is set at 2 ppm (Fig. 2B). The isobaric interference is greatly reduced in the reconstructed ion chromatogram at the $\mathrm{MS}^{3}$ scan stage (Fig. $2 \mathrm{~F}$ ). The mass spectra of $\left[{ }^{14} \mathrm{C}\right]-\mathrm{PhIP}$ and its internal standard $\left[{ }^{2} \mathrm{H}_{3} \mathrm{C}\right]-\mathrm{PhIP}$ in human plasma are shown in Supporting information, Fig. S5. The product ion spectra at the $\mathrm{MS}^{2}$ and $\mathrm{MS}^{3}$ scan stages are in excellent agreement to the mass spectra of the reference standards (Fig. 2).

\section{Kinetics and Recovery of $\left[{ }^{14} \mathrm{C}\right]-\mathrm{PhIP}$ Bound to Albumin in Human Volunteers}

A kinetics experiment was conducted in vitro to determine the effect of temperature and duration of acid hydrolysis on the recovery of $\left[{ }^{14} \mathrm{C}\right]-\mathrm{PhIP}$. In a plasma sample of a volunteer, which was collected $24 \mathrm{~h}$ after dosing, $\left[{ }^{14} \mathrm{C}\right]-\mathrm{PhIP}$ was below the LOD prior to treatment of albumin with acid or pronase E digestion (Fig. 3). The amount of acid-labile $\left[{ }^{14} \mathrm{C}\right]-\mathrm{PhIP}$ released from albumin was estimated at a level of $16 \mathrm{fg} / \mathrm{mg}$ albumin following acid hydrolysis $(0.1 \mathrm{~N} \mathrm{HCl})$ at $37{ }^{\circ} \mathrm{C}$ for $30 \mathrm{~min}$, and the amount of the released $\left[{ }^{14} \mathrm{C}\right]-\mathrm{PhIP}$ peaked at $\sim 54 \mathrm{fg} / \mathrm{mg}$ albumin at $60 \mathrm{~min}$ (Fig. 3). The level of $\left[{ }^{14} \mathrm{C}\right]-\mathrm{PhIP}$ was not significantly different in the samples after hydrolysis at $37{ }^{\circ} \mathrm{C}$ for 60 and $180 \mathrm{~min}$ (Fig. 3), or following acid hydrolysis at $65^{\circ} \mathrm{C}$ for $180 \mathrm{~min}$ (data not shown, $\mathrm{p}>0.05$ ).

\section{Levels of $\left[{ }^{14} \mathrm{C}\right]-\mathrm{PhIP}$ Adduct Formation with Albumin in Humans}

The levels of $\left[{ }^{14} \mathrm{C}\right]-\mathrm{PhIP}$ in albumin purified from the plasma of four volunteers following acid hydrolysis or proteolytic digestion with pronase $\mathrm{E}$ is reported in Table 5. The amount of acid labile $\left[{ }^{14} \mathrm{C}\right]-\mathrm{PhIP}$ bound to albumin ranged from 28 to $57 \mathrm{fg} / \mathrm{mg}$ albumin collected $24 \mathrm{~h}$ after dosing $\left(\mathrm{T}_{24}\right)$. These estimates were between 7.2 and $21.3 \%$ of the amount of $\left[{ }^{14} \mathrm{C}\right]-$ $\mathrm{PhIP}$ bound to albumin based on AMS measurements performed when the samples were originally collected. We also examined for 5-HO- $\left[{ }^{14} \mathrm{C}\right]-\mathrm{PhIP}$ following acid or pronase treatment of albumin, using 5-HO- $\left[{ }^{2} \mathrm{H}_{3} \mathrm{C}\right]-\mathrm{PhIP}$ as an internal standard. Since the same amounts of $\left[{ }^{2} \mathrm{H}_{3} \mathrm{C}\right]-\mathrm{PhIP}$ and 5-HO- $\left[{ }^{2} \mathrm{H}_{3} \mathrm{C}\right]$-PhIP injected for UPLC/MS analysis yield similar ion counts of peak areas at $\mathrm{MS}^{3}$ scan stage (with no isobaric interferences), we estimate the values of LOD and LOQ values of 5-HO- $\left[{ }^{2} \mathrm{H}_{3}\right]-\mathrm{PhIP}$ to be close to that of $\mathrm{PhIP}$ and $\left[{ }^{14} \mathrm{C}\right]$-PhIP. 5-HO-[ $\left[{ }^{14} \mathrm{C}\right]-\mathrm{PhIP}$ was below the LOD in human plasma of these subject $(<$ $11 \mathrm{fg} / \mathrm{mg}$ albumin) (Fig. S-6). 


\section{Stability of $\left[{ }^{14} \mathrm{C}\right]-\mathrm{PhIP}-$ Acid Labile Albumin Adducts}

The stability of the presumed $\left[{ }^{14} \mathrm{C}\right]$-PhIP-sulfinamide adduct formed in vivo was examined over time in vitro at $37{ }^{\circ} \mathrm{C}$, following a 2-fold dilution with commercial human plasma and measurement, by UPLC-ESI/MS ${ }^{3}$, of the remaining acid-labile $\left[{ }^{14} \mathrm{C}\right]-\mathrm{PhIP}$ bound to albumin over seven days. We acknowledge that these samples were stored for nearly 20 years at $-80^{\circ} \mathrm{C}$, and the stability of acid-labile adducts over this prolonged period of storage has not been determined. The level of acid-labile $\left[{ }^{14} \mathrm{C}\right]-\mathrm{PhIP}$ bound to albumin decreased by $17 \%$ and 39\% after human plasma was incubated for $6 \mathrm{~h}$ and $24 \mathrm{~h}$, and then by $80 \%$ after 7 days, under neutral $\mathrm{pH}$ conditions (Fig. 4). The curve approximates a first-order rate decay, and the half-life of labile $\left[{ }^{14} \mathrm{C}\right]-\mathrm{PhIP}$ bound to albumin is estimated at $\sim 50 \mathrm{~h}$. However, the inclusion of the last time point at 7 days may indicate that the rate of decay is biphasic. Additional time points would be required to fully characterize the decay curve of the labile $\left[{ }^{14} \mathrm{C}\right]$-PhIP albumin adduct. We also incubated HONH-PhIP modified with albumin in vitro and diluted it in human plasma; the level of PhIP bound to albumin (primarily as the sulfinamide) also decreased at a similar rate to the adduct formed in vivo (data not shown). These data suggest that the acid-labile albumin adducts of PhIP may have a shorter half-life in vivo than albumin, which is approximately 20 days. ${ }^{33}$

\section{DISCUSSION}

The $\mathrm{Cys}^{34}$ of rodent and human albumin reacts with $\mathrm{N}$-oxidized metabolites of $\mathrm{PhIP},{ }^{16,20,21}$ and many other electrophiles to form adducts. ${ }^{12}$ UPLC-MS ${ }^{\mathrm{n}}$ characterization of proteolytic digest of human albumin modified in vitro with $\mathrm{N}$-oxidized metabolites of PhIP revealed that the $\mathrm{Cys}^{34}$ residue is the major site of adduction and forms the sulfinamide adduct with $\mathrm{PhIP}$ (Scheme 1). ${ }^{20,21}$ We measured the presumed Cys containing sulfinamide (C-[SO]$\left.\left[{ }^{14} \mathrm{C}\right]-\mathrm{PhIP}\right)$ formed in vivo indirectly, following mild acid treatment or pronase digestion of the purified albumin. Acid or pronase treatment results in hydrolysis of the sulfinamide linkage and regenerates $\mathrm{PhIP}$. The $\mathrm{C}^{*}$ sulfonamide $\left(\mathrm{C}-\left[\mathrm{SO}_{2}\right]-\mathrm{PhIP}\right)$ adduct is stable toward acid or protease treatment, and does not produce PhIP. The proposed the S-N linked adduct of the PhIP sulfenamide undergoes hydrolysis by mild acid treatment or proteolysis to produce both PhIP and 5-HO- $\left[{ }^{14} \mathrm{C}\right]-\mathrm{PhIP}$ (Scheme 1). However, we did not detect 5-HO$\left[{ }^{14} \mathrm{C}\right]-\mathrm{PhIP}$ in the human samples. In contrast, 5-HO-PhIP was identified as a major product recovered in pronase hydrolysates of rat albumin reacted with $N$-acetoxy-PhIP, ${ }^{16}$ Our laboratory also identified 5-HO-PhIP in the pronase digest of albumin recovered from human hepatocytes treated with $\mathrm{PhIP},{ }^{21}$ and from human albumin treated with $\mathrm{N}$-acetoxyPhIP in vitro, but not with albumin modified with HONH-PhIP. ${ }^{18,21}$ Thus, we deduce that a large portion of the acid labile $\left[{ }^{14} \mathrm{C}\right]-\mathrm{PhIP}$ bound to albumin in humans is likely present as the sulfinamide linked adduct, which is formed by reaction of nitroso-PhIP with $\mathrm{Cys}^{34}$ of albumin (Scheme 1). ${ }^{18,21}$ However, these plasma samples were stored at $-80^{\circ} \mathrm{C}$ ever since the study was conducted in $1997-1998,{ }^{24}$ a labile $\left[{ }^{14} \mathrm{C}\right]-\mathrm{PhIP}$ sulfenamide may have undergone hydrolysis over this long time period.

Our studies on the characterization of the reactivity of the N-oxidized metabolites of PhIP with albumin in vitro revealed that $>60 \%$ of the PhIP bound to albumin was acid-labile and recovered as PhIP (Scheme 1). ${ }^{20}$ A very high percentage of this acid labile PhIP bound to 
albumin occurs at $\mathrm{Cys}^{34}$ since pretreatment of albumin with 4-chloromercuribenzoic acid, a selective agent that binds to $\mathrm{Cys}^{34}$ of albumin, ${ }^{34}$ abolished most of the PhIP species bound as an acid labile albumin adduct. The percent of $\left[{ }^{14} \mathrm{C}\right]-\mathrm{PhIP}$ bound to albumin in humans and recovered as $\mathrm{PhIP}$, following protein purification and acid treatment, is considerably lower $(7.2-21.3 \%)$ than those levels observed with albumin modified in vitro with $\mathrm{N}$-oxidized $\mathrm{PhIP}$ metabolites. We note that the stability of the sulfinamide $\mathrm{C}-[\mathrm{SO}]-\left[{ }^{14} \mathrm{C}\right]-\mathrm{PhIP}$ has not been assessed under prolonged storage conditions and some portion of the adduct may have undergone hydrolysis. A portion of the sulfinamide $\mathrm{C}$-[SO]-[ $\left.{ }^{14} \mathrm{C}\right]-\mathrm{PhIP}$ also could have undergone oxidation to form the acid-stable sulfonamide $\mathrm{C}$ - $\left[\mathrm{SO}_{2}\right]-\left[{ }^{14} \mathrm{C}\right]-\mathrm{PhIP}$ during prolonged storage (Scheme 1). ${ }^{19}$ Other sites of PhIP adduct formation with albumin also occur. $N$-sulfooxy-2-amino-1-methyl-6-phenylimidazo[4,5- $b$ ]pyridine ( $N$-sulfooxy-PhIP), a likely genotoxic metabolite of PhIP formed in humans, ${ }^{35}$ reacts in vitro with the sole tryptophan $\left(\operatorname{Tr}^{214}\right)$ residue of human albumin to form a minor adduct that is recovered by trypsin digestion as $\left.\mathrm{AW}^{*}{ }^{[\mathrm{PhIP}}\right] \mathrm{AVAR} .{ }^{21}$ Another adduction product was detected at His residue(s) following pronase digestion of albumin modified with $N$-sulfooxy-PhIP. ${ }^{21}$ The proposed structures of these adducts are depicted in Figure 5. Neither adduct undergoes proteolysis to regenerate $\mathrm{PhIP}$, although the chemical stability of the adducts towards acid treatment was not investigated. ${ }^{21}$ The amounts of $\mathrm{AW}^{*}[\mathrm{PhIP}] \mathrm{AVA}$ and His albumin adducts formed in vivo may be larger than those which occur in vitro. Because of the very large amounts of non-modified peptides in the proteolytic digest of in vivo samples, we do not yet have selective enrichment methods to isolate Trp and His adducts of PhIP for measurement by UPLC-ESI/MS .

An LC-MS/MS method with a triple quadrupole MS was recently developed to quantify the level of HAAs released from acid treatment of albumin in humans: the LOD and LOQ values reported for PhIP were 125 and $375 \mathrm{fg} \mathrm{PhIP} / \mathrm{mg}$ albumin, respectively (the albumin content in human plasma $\sim 40 \mathrm{mg} / \mathrm{mL}) .{ }^{26}$ The authors concluded that the formation of acidlabile albumin HAA adducts was very low and would not be viable biomarkers to biomonitor HAA exposure in humans. However, the volunteers were on a free-choice diet, and the amount of PhIP ingested was not known. Our sensitive UPLC-MS ${ }^{\mathrm{n}}$ method employing the high resolution accurate mass measurement of the Orbitrap at the $\mathrm{MS}^{3}$ scan stage has superior sensitivity to the triple quadrupole MS method; the LOD and LOQ values are 11 and $33 \mathrm{fg} \mathrm{PhIP/mg} \mathrm{albumin,} \mathrm{respectively.} \mathrm{Our} \mathrm{kinetic} \mathrm{studies} \mathrm{in} \mathrm{vitro} \mathrm{with}\left[{ }^{14} \mathrm{C}\right]-\mathrm{PhIP}$ bound to albumin in isolated plasma reveal the adduct has a half-life of about $50 \mathrm{~h}$, which is considerably less than the $\sim 20$ day half-life of albumin in humans. ${ }^{33}$ A kinetics study measuring PhIP albumin adduct formation and decay over time with healthy subjects on a diet containing known amounts of PhIP is required to determine if the acid labile $\mathrm{PhIP}$ albumin adduct can be implemented in human biomonitoring studies.

\section{Supplementary Material}

Refer to Web version on PubMed Central for supplementary material.

\section{Acknowledgments}

Funding Sources. 
This research was supported by Grant 2R01CA122320 (R.J.T.). Mass spectrometry was carried out in the Analytical Biochemistry Shared Resource of the Masonic Cancer Center, University of Minnesota, funded in part by Cancer Center Support Grant CA-077598.

\section{ABBREVIATIONS}

AMS

$\beta \mathrm{ME}$

IQ

5-HO-PhIP

$N$-acetoxy-PhIP

HONH-PhIP

NO-PhIP

$N$-sulfooxy-PhIP

Hb

HAA

NATs

MS

$m$-CPBA

SIM

SPE

SULTs

UPLC-MS $^{n}$ accelerator mass spectrometry

$\beta$-mercaptoethanol

2-amino-3-methylimidazo[4,5- $f$ quinoline $\mathrm{PhIP}, 2$ -

amino-1-methyl-6-phenylimidazo[4,5-b]pyridine

2-amino-1-methyl-6-(5-hydroxy)-phenylimidazo[4,5-

$b$ ]pyridine

$\mathrm{N}$-(acetyloxy)-2-amino-1-methyl-6-phenylimidazo[4,5-

$b$ ]pyridine

2-hydroxyamino-1-methyl-6-phenylimidazo[4,5-b]pyridine

2-nitroso-1-methyl-6-phenylimidazo[4,5-b]pyridine

$\mathrm{N}$-sulfooxy-2-amino-1-methyl-6-phenylimidazo[4,5-

$b$ ]pyridine

hemoglobin

heterocyclic aromatic amines

$N$-acetyltransferases

mass spectrometry

meta-chloroperoxybenzoic acid

selected ion monitoring

solid phase extraction

sulfotransferases

ultraperformance liquid chromatography-multistage scan mass spectrometry

\section{References}

1. Sugimura T, Wakabayashi K, Nakagama H, Nagao M. Heterocyclic amines: Mutagens/carcinogens produced during cooking of meat and fish. Cancer Sci. 2004; 95:290-299. [PubMed: 15072585]

2. Matsumoto, Takashi, Yoshida, Daisuke, Tomita, Hideo. Determination of mutagens, amino-acarbolines in grilled foods and cigarette smoke condensate. Cancer Letters. 1981; 12:105-110. [PubMed: 7272995]

3. Felton, JS., Jagerstad, M., Knize, MG., Skog, K., Wakabayashi, K. Contents in foods, beverages and tobacco. In: Nagao, M., Sugimura, T., editors. Food Borne Carcinogens Heterocyclic Amines. John Wiley \& Sons Ltd; Chichester, England: 2000. p. 31-71. 
4. Knize MG, Dolbeare FA, Carroll KL, Moore DH, Felton JS. Effect of cooking time and temperature on the heterocyclic amine content of fried beef patties. Food Chem Toxicol. 1994; 32:595-603. [PubMed: 8045472]

5. Sinha R, Rothman N, Brown ED, Salmon CP, Knize MG, Swanson CS, Rossi SC, Mark SD, Levander OA, Felton JS. High concentrations of the carcinogen 2-amino-1-methyl-6phenylimidazo[4,5-b]pyridine (PhIP) occur in chicken but are dependent on the cooking method. Cancer Res. 1995; 55:4516-4519. [PubMed: 7553619]

6. Turesky RJ, Le Marchand L. Metabolism and biomarkers of heterocyclic aromatic amines in molecular epidemiology studies: lessons learned from aromatic amines. Chem Res Toxicol. 2011; 24:1169-1214. [PubMed: 21688801]

7. Bouvard V, Loomis D, Guyton KZ, Grosse Y, Ghissassi FE, Benbrahim-Tallaa L, Guha N, Mattock H, Straif K. Carcinogenicity of consumption of red and processed meat. Lancet Oncol. 2015; 16:1599-1600. [PubMed: 26514947]

8. Jarabek AM, Pottenger LH, Andrews LS, Casciano D, Embry MR, Kim JH, Preston RJ, Reddy MV, Schoeny R, Shuker D, Skare J, Swenberg J, Williams GM, Zeiger E. Creating context for the use of DNA adduct data in cancer risk assessment: I. Data organization. Crit Rev Toxicol. 2009; 39:659678. [PubMed: 19743944]

9. Himmelstein MW, Boogaard PJ, Cadet J, Farmer PB, Kim JH, Martin EA, Persaud R, Shuker DE. Creating context for the use of DNA adduct data in cancer risk assessment: II. Overview of methods of identification and quantitation of DNA damage. Crit Rev Toxicol. 2009; 39:679-694. [PubMed: 19743945]

10. Skipper PL, Peng X, SooHoo CK, Tannenbaum SR. Protein adducts as biomarkers of human carcinogen exposure. Drug Metab Rev. 1994; 26:111-124. [PubMed: 8082561]

11. Liebler DC. Proteomic approaches to characterize protein modifications: new tools to study the effects of environmental exposures. Environ Health Perspect. 2002; 110(Suppl 1):3-9. [PubMed: 11834459]

12. Rappaport SM, Li H, Grigoryan H, Funk WE, Williams ER. Adductomics: Characterizing exposures to reactive electrophiles. Toxicol Lett. 2012; 213:83-90. [PubMed: 21501670]

13. Aldini G, Regazzoni L, Orioli M, Rimoldi I, Facino RM, Carini M. A tandem MS precursor-ion scan approach to identify variable covalent modification of albumin Cys34: a new tool for studying vascular carbonylation. J Mass Spectrom. 2008; 43:1470-1481. [PubMed: 18457351]

14. Turesky RJ, Skipper PL, Tannenbaum SR. Binding of 2-amino-3-methylimidazo[4,5-f]quinoline to hemoglobin and albumin in vivo in the rat. Identification of an adduct suitable for dosimetry. Carcinogenesis. 1987; 8:1537-1542. [PubMed: 3652389]

15. Lynch AM, Murray S, Boobis AR, Davies DS, Gooderham NJ. The measurement of MeIQx adducts with mouse haemoglobin in vitro and in vivo: implications for human dosimetry. Carcinogenesis. 1991; 12:1067-1072. [PubMed: 2044186]

16. Reistad R, Frandsen H, Grivas S, Alexander J. In vitro formation and degradation of 2-amino-1methyl-6-phenylimidazo[4,5-b]pyridine (PhIP) protein adducts. Carcinogenesis. 1994; 15:25472552. [PubMed: 7955104]

17. Chepanoske CL, Brown K, Turteltaub KW, Dingley KH. Characterization of a peptide adduct formed by N-acetoxy-2-amino-1-methyl-6-phenylimidazo[4,5- $b$ ]pyridine (PhIP), a reactive intermediate of the food carcinogen PhIP. Food Chem Toxicol. 2004; 42:1367-1372. [PubMed: 15207388]

18. Peng L, Dasari S, Tabb DL, Turesky RJ. Mapping serum albumin adducts of the food-borne carcinogen 2-amino-1-methyl-6-phenylimidazo[4,5- $b$ ]pyridine by data-dependent tandem mass spectrometry. Chem Res Toxicol. 2012; 25:2179-2193. [PubMed: 22827630]

19. Peng L, Turesky RJ. Capturing labile sulfenamide and sulfinamide serum albumin adducts of carcinogenic arylamines by chemical oxidation. Anal Chem. 2013; 85:1065-1072. [PubMed: 23240913]

20. Peng L, Turesky RJ. Mass spectrometric characterization of 2-amino-1-methyl-6phenylimidazo[4,5- $b$ ]pyridine $\mathrm{N}$-oxidized metabolites bound at $\mathrm{Cys}^{34}$ of human serum albumin. Chem Res Toxicol. 2011; 24:2004-2017. [PubMed: 21916490] 
21. Wang Y, Peng L, Bellamri M, Langouet S, Turesky RJ. Mass spectrometric characterization of human serum albumin adducts formed with $\mathrm{N}$-oxidized metabolites of 2-amino-1methylphenylimidazo[4,5- $b$ ]pyridine in human plasma and hepatocytes. Chemical research in toxicology. 2015; 28:1045-1059. [PubMed: 25815793]

22. Reistad R, Rossland OJ, Latva-Kala KJ, Rasmussen T, Vikse R, Becher G, Alexander J. Heterocyclic aromatic amines in human urine following a fried meat meal. Food Chem Toxicol. 1997; 35:945-955. [PubMed: 9463528]

23. Garner RC, Lightfoot TJ, Cupid BC, Russell D, Coxhead JM, Kutschera W, Priller A, Rom W, Steier P, Alexander DJ, Leveson SH, Dingley KH, Mauthe RJ, Turteltaub KW. Comparative biotransformation studies of MeIQx and PhIP in animal models and humans. Cancer Lett. 1999; 143:161-165. [PubMed: 10503897]

24. Dingley KH, Curtis KD, Nowell S, Felton JS, Lang NP, Turteltaub KW. DNA and protein adduct formation in the colon and blood of humans after exposure to a dietary-relevant dose of 2amino-1-methyl-6-phenylimidazo[4,5- $b$ ]pyridine. Cancer Epidemiol Biomarkers Prev. 1999; 8:507-512. [PubMed: 10385140]

25. Magagnotti C, Orsi F, Bagnati R, Celli N, Rotilio D, Fanelli R, Airoldi L. Effect of diet on serum albumin and hemoglobin adducts of 2-amino-1-methyl-6-phenylimidazo[4,5-b]pyridine (PhIP) in humans. Int J Cancer. 2000; 88:1-6. [PubMed: 10962432]

26. Cooper KM, Brennan SF, Woodside JV, Cantwell M, Guo X, Mooney M, Elliott CT, Cuskelly GJ. Acid-labile protein-adducted heterocyclic aromatic amines in human blood are not viable biomarkers of dietary exposure: A systematic study. Food Chem Toxicol. 2016; 91:100-107. [PubMed: 26993956]

27. Turesky RJ, Lang NP, Butler MA, Teitel CH, Kadlubar FF. Metabolic activation of carcinogenic heterocyclic aromatic amines by human liver and colon. Carcinogenesis. 1991; 12:1839-1845. [PubMed: 1934265]

28. Peng L, Turesky RJ. Optimizing proteolytic digestion conditions for the analysis of serum albumin adducts of 2-amino-1-methyl-6-phenylimidazo[4,5- $b$ ]pyridine, a potential human carcinogen formed in cooked meat. J Proteomics. 2014; 103:267-278. [PubMed: 24698664]

29. Fede JM, Thakur AP, Gooderham NJ, Turesky RJ. Biomonitoring of 2-amino-1-methyl-6phenylimidazo[4,5-b]pyridine (PhIP) and its carcinogenic metabolites in urine. Chem Res Toxicol. 2009; 22:1096-1105. [PubMed: 19441775]

30. Toribio F, Moyano E, Puignou L, Galceran MT. Multistep mass spectrometry of heterocyclic amines in a quadrupole ion trap mass analyser. J Mass Spectrom. 2002; 37:812-828. [PubMed: 12203675]

31. Guo, Jingshu, Yonemori, Kim, Le Marchand, Loic, Turesky, Robert J. A Method to Biomonitor the Cooked Meat Carcinogen 2-Amino-1-methyl-6-phenylimidazo[4,5-b]pyridine (PhIP) in Dyed Hair by Ultra Performance Liquid Chromatography-Orbitrap High Resolution Multistage Mass Spectrometry. Analytical Chemistry. 2015; 87:5872-5877. [PubMed: 25969997]

32. Validation of Analytical Procedures: Text and Methodology Q2(R1). International Conference on Harmonization. Nov. 2005 http://www.ich.org/products/guidelines/quality/quality-single/article/ validation-of-analytical-procedures-text-and-methodology.html

33. Peters T Jr. Serum albumin. Adv Protein Chem. 1985; 37:161-245. [PubMed: 3904348]

34. Boyer PD. Spectrophotometric Study of the Reaction of Protein Sulfhydryl Groups with Organic Mercurials. J Am Chem Soc. 1954; 76:4331-4337.

35. Nowell S, Ambrosone CB, Ozawa S, MacLeod SL, Mrackova G, Williams S, Plaxco J, Kadlubar FF, Lang NP. Relationship of phenol sulfotransferase activity (SULT1A1) genotype to sulfotransferase phenotype in platelet cytosol. Pharmacogenetics. 2000; 10:789-797. [PubMed: 11191883] 


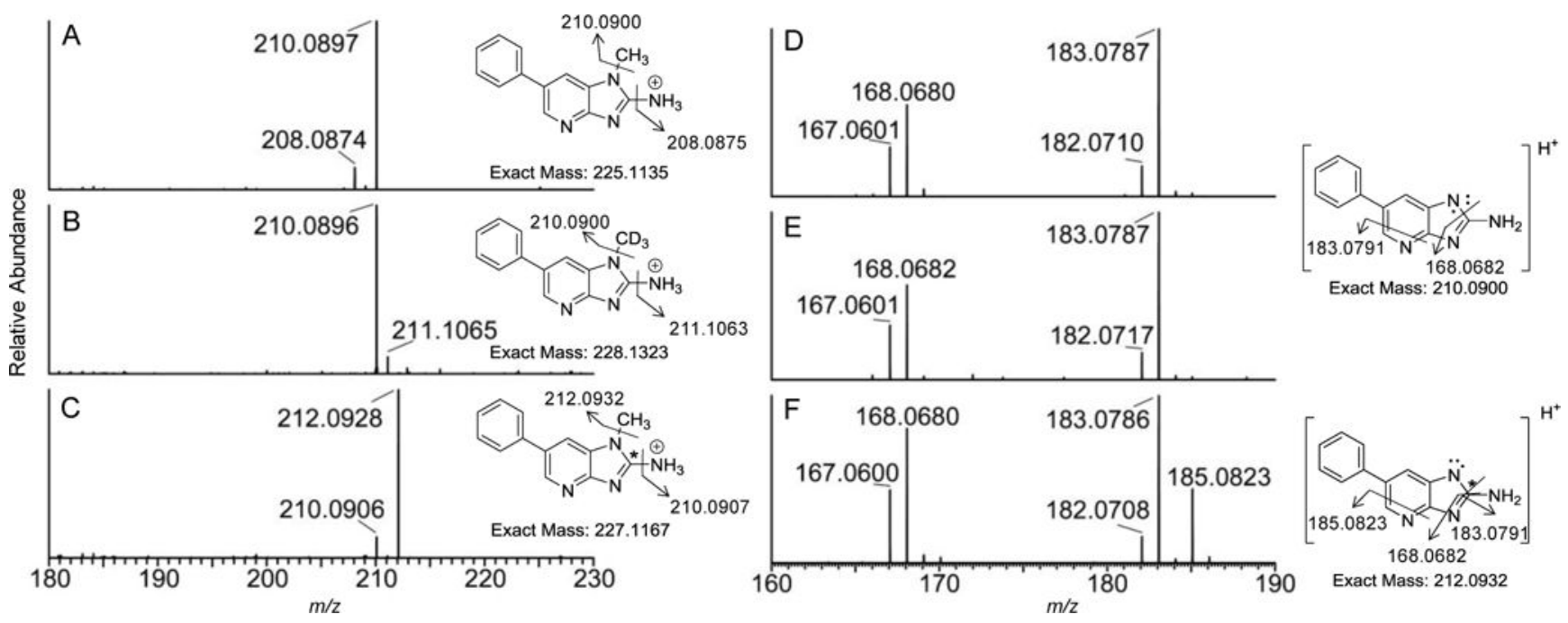

Figure 1.

Product ion spectra of (A) PhIP ([M+H $]^{+} \mathrm{m} / \mathrm{z} 225.1>$ ), (B) $\left.{ }^{2} \mathrm{H}_{3} \mathrm{C}\right]-\mathrm{PhIP}\left([\mathrm{M}+\mathrm{H}]^{+} \mathrm{m} / \mathrm{z}\right.$ $228.1>$ ), and $(\mathrm{C})\left[{ }^{14} \mathrm{C}\right]-\mathrm{PhIP}\left([\mathrm{M}+\mathrm{H}]{ }^{+} \mathrm{m} / \mathrm{z} 227.1>\right.$ ) of $\left[{ }^{14} \mathrm{C}\right]-\mathrm{PhIP}$ and $\left[{ }^{2} \mathrm{H}_{3} \mathrm{C}\right]-\mathrm{PhIP}$ reference standards at the $\mathrm{MS}^{2}$ scan stage. Product ion spectra of (D) PhIP $\left([\mathrm{M}+\mathrm{H}]^{+} \mathrm{m} / \mathrm{z}\right.$ $225.1>210.1>$ ), (E) $\left[{ }^{2} \mathrm{H}_{3} \mathrm{C}\right]-\mathrm{PhIP}\left([\mathrm{M}+\mathrm{H}]^{+} \mathrm{m} / z 228.1>210.1>\right)$, and $(\mathrm{F})\left[{ }^{14} \mathrm{C}\right]-\mathrm{PhIP}([\mathrm{M}$ $+\mathrm{H}]^{+} \mathrm{m} / z 227.1>212.1>$ ) of $\left[{ }^{14} \mathrm{C}\right]$-PhIP and $\left[{ }^{2} \mathrm{H}_{3} \mathrm{C}\right]-\mathrm{PhIP}$ standards at $\mathrm{MS}^{3}$ scan stage. The $\mathrm{m} / \mathrm{z}$ values shown in the structure scheme are the calculated values. The $\mathrm{m} / \mathrm{Z}$ values shown in the mass spectra are the observed values. 
Commercial human plasma

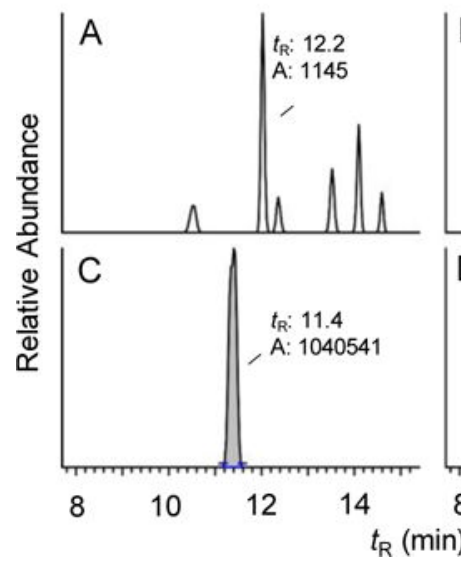

$\left[{ }^{14} \mathrm{C}\right]-\mathrm{PhlP}$ human plasma
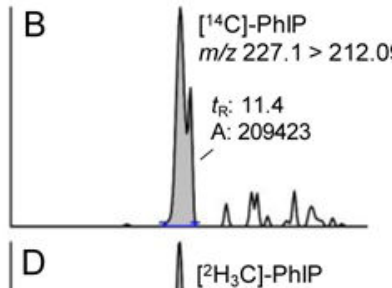

$\mathrm{m} / \mathrm{z} 228.1>210.0900$

$t_{\mathrm{R}}: 11.4$

A: 915239

Figure 2.

Reconstructed ion chromatograms at $\mathrm{MS}^{2}$ stage of $(\mathrm{A}, \mathrm{B})\left[{ }^{14} \mathrm{C}\right]-\mathrm{PhIP}\left([\mathrm{M}+\mathrm{H}]^{+} \mathrm{m} / \mathrm{z} 227.1>\right.$ 212.0932) recovered from human plasma of volunteer 2 given a capsule containing $56 \mathrm{mCi} /$ mmol $\left[{ }^{14} \mathrm{C}\right]-\mathrm{PhIP}$. Reconstructed ion chromatograms at MS ${ }^{3}$ stage of $(\mathrm{E}, \mathrm{F})\left[{ }^{14} \mathrm{C}\right]-\mathrm{PhIP}([\mathrm{M}$ $\left.+\mathrm{H}]^{+} \mathrm{m} / \mathrm{z} 227.1>212.0932>168.0682,183.0791,185.0823\right)$ recovered from in in vivo human plasma. (C, D, G, H) $\left[{ }^{2} \mathrm{H}_{3} \mathrm{C}\right]-\mathrm{PhIP}$ were spiked to the samples as internal standards. The mass extraction window was $\pm 5 \mathrm{ppm}$. 


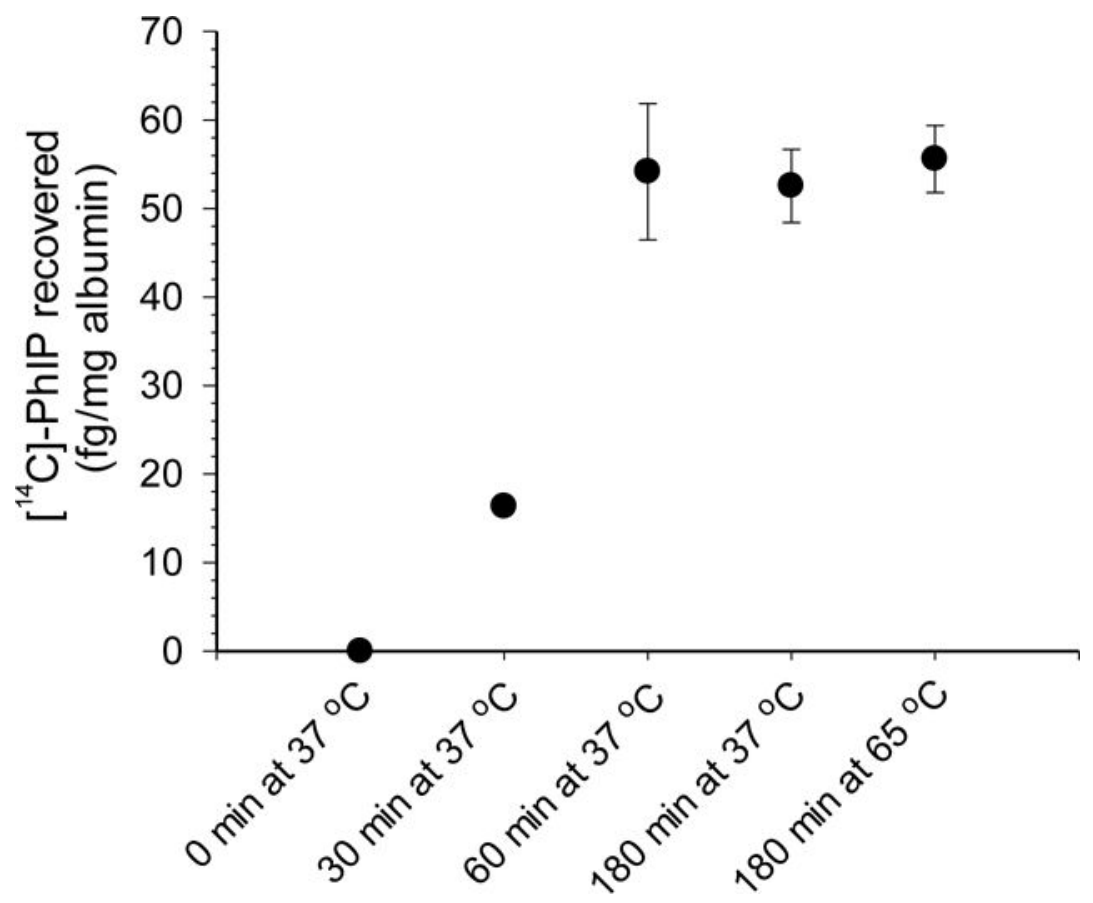

Figure 3.

Kinetics study on acid hydrolysis of $\left[{ }^{14} \mathrm{C}\right]$-PhIP-albumin obtained following purification of albumin from plasma of volunteer 10 given a capsule containing $42 \mathrm{mCi} / \mathrm{mmol}\left[{ }^{14} \mathrm{C}\right]-\mathrm{PhIP}$. Each time point was measured in triplicate and reported as the mean \pm SD. Transitions of $\left[{ }^{14} \mathrm{C}\right]$-PhIP were monitored $\left([\mathrm{M}+\mathrm{H}]^{+} \mathrm{m} / \mathrm{z} 227.1>212.0932>168.0682,183.0791\right.$, $185.0823)$. The mass extraction window was $\pm 5 \mathrm{ppm}$. 


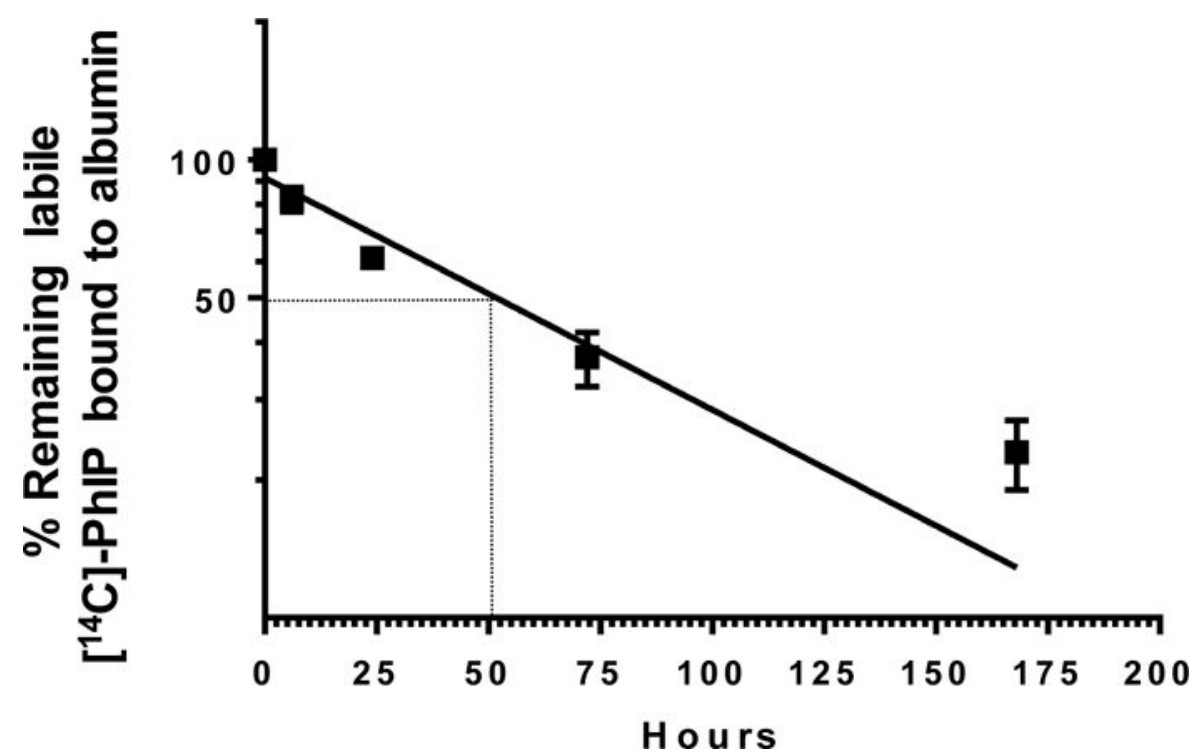

Figure 4.

The level of labile $\left[{ }^{14} \mathrm{C}\right]-\mathrm{PhIP}$ remaining bound to albumin of volunteer 7 given a capsule containing $42 \mathrm{mCi} / \mathrm{mmol}\left[{ }^{14} \mathrm{C}\right]-\mathrm{PhIP}$ as a function of time when the human plasma was incubated at $37^{\circ} \mathrm{C}$ in vitro, following dilution with commercial plasma. Values represent the mean $\pm \mathrm{SD}(n=3)$. 


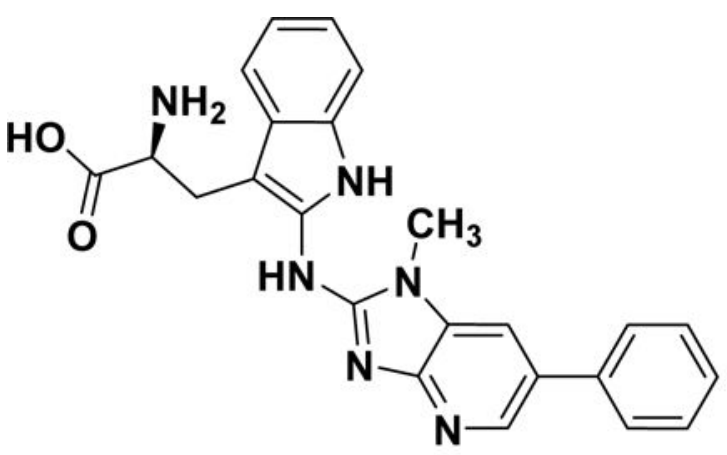

PhIP-Trp

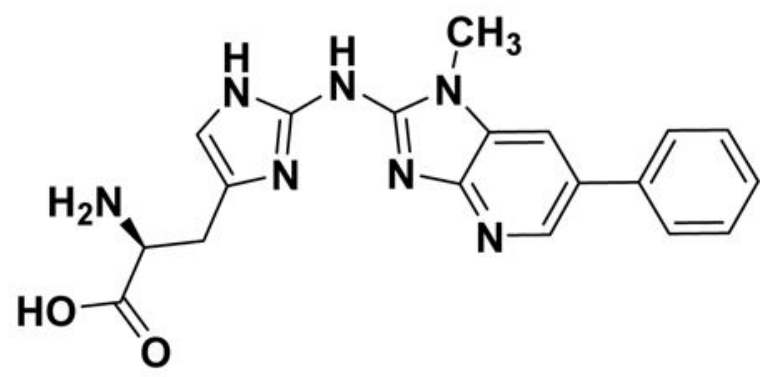

PhIP-His

Figure 5.

Proposed structures of PhIP adduct formed at $\operatorname{Trp}^{214}$ and His residues of albumin. Mass spectral data support structures formed between the C-2 indole atom of Trp and the C-2 imidazole atom of histidine with the $\mathrm{N}$-oxidized $\mathrm{NH}_{2}$-group of PhIP. ${ }^{21}$ 


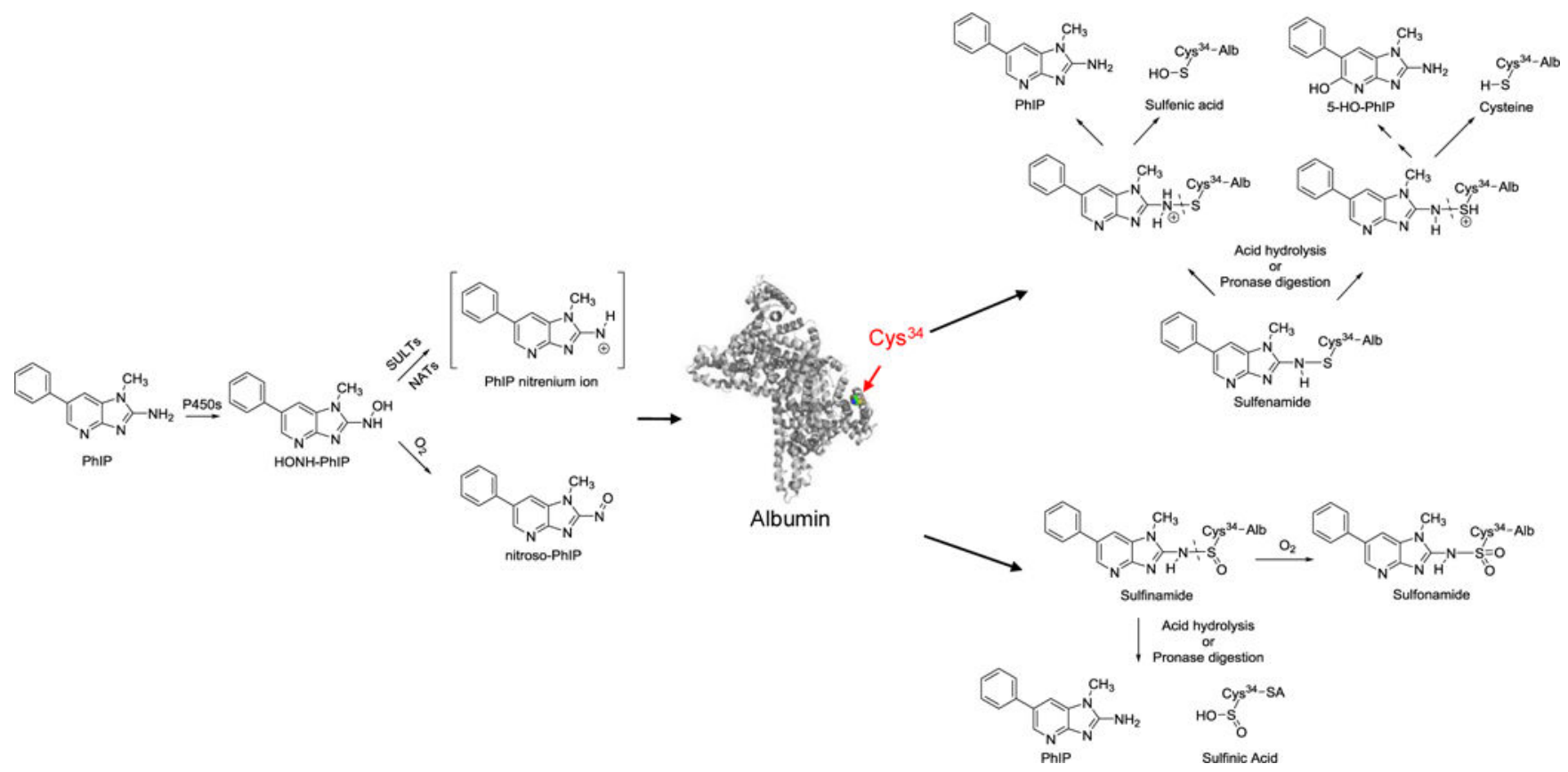

Scheme 1.

Formation of albumin (Alb) sulfenamide, sulfinamide and sulfonamide adducts formed with $\mathrm{N}$-oxidized metabolites of PhIP, and proposed mechanism of hydrolysis of the linkages to produce PhIP and 5-HO-PhIP. NATs, N-acetyltransferases; SULTs, sulfotransferases. 


\section{Table 1}

Amounts of PhIP recovered from LQQC*PFEDHVK sulfinamide and sulfonamide peptides after acid hydrolysis or digestion with pronase $\mathrm{E}$.

\begin{tabular}{cccc}
\hline & $\begin{array}{c}\text { No treatment } \\
\mathrm{fmol}\end{array}$ & $\begin{array}{c}\text { Acid Hydrolysis } \\
\mathrm{fmol}\end{array}$ & $\begin{array}{c}\text { Pronase E Digestion } \\
\mathrm{fmol}\end{array}$ \\
LQQC*PFEDHVK sulfinamide & $63.8 \pm 15.3$ & $\mathrm{ND}$ & $\mathrm{ND}$ \\
PhIP & $3.7 \pm 0.3$ & $64.3 \pm 0.2$ & $50.6 \pm 0.2$ \\
& $\mathrm{fmol}$ & $\mathrm{fmol}$ & $\mathrm{fmol}$ \\
LQQC*PFEDHVK Sulfonamide & $38.1 \pm 0.1$ & $31.3 \pm 0.1$ & $\mathrm{ND}$ \\
PhIP & $\mathrm{ND}$ & $\mathrm{ND}$ & $\mathrm{ND}$ \\
C* sulfonamide & $\mathrm{ND}$ & $\mathrm{ND}$ & $19.5 \pm 0.1$ \\
\hline
\end{tabular}

${ }^{a}$ PhIP and peptides were determined by UPLC-MS ${ }^{2}$ analysis of LQQC*PFEDHVK sulfinamide $\left([\mathrm{M}+3 \mathrm{H}]^{3+} \mathrm{m} / z 527.9>225.1,679.1\right)$, PhIP ([M $\left.+\mathrm{H}]^{+} \mathrm{m} / \mathrm{z} 225.1>210.1\right)$, and $\mathrm{C}^{*} \mathrm{PF}$ sulfonamide $\left([\mathrm{M}+\mathrm{H}]^{+} \mathrm{m} / \mathrm{z} 620.1>225.1,602.1\right),\left[{ }^{2} \mathrm{H} 3 \mathrm{C}\right]-\mathrm{PhIP}\left([\mathrm{M}+\mathrm{H}]^{+} \mathrm{m} / \mathrm{z} 228.1>210.1\right)$ was used the internal standard. Values are reported as the mean $\pm \mathrm{SD}(n=3)$. ND, not detected, below the limit of detection. The amount of $\mathrm{C}^{*}$ sulfonamide is an estimate based on the response relative to that of $\left[{ }^{2} \mathrm{H}_{3} \mathrm{C}\right]-\mathrm{PhIP}$. 
Table 2

The measurement of PhIP recovered from in vitro HONH-PhIP (45 pmol) modified commercial human albumin ( $15 \mathrm{pmol})$, subsequently treated with or without $m$-CPBA ( $3 \times$ molar excess of albumin). ${ }^{a}$

\begin{tabular}{|c|c|c|c|c|}
\hline & \multicolumn{2}{|c|}{$\begin{array}{l}\text { HONH-PhIP modified human albumin Without oxidization } \\
\text { by } m \text {-CPBA }\end{array}$} & \multicolumn{2}{|c|}{$\begin{array}{c}\text { HONH-PhIP modified human albumin With oxidation by } m \text { - } \\
\text { CPBA }\end{array}$} \\
\hline & $\begin{array}{l}\text { Acid hydrolysis (fmol PhIP/ } \\
\text { pmol albumin) }\end{array}$ & $\begin{array}{l}\text { Pronase E digestion (fmol } \\
\text { PhIP/pmol albumin) }\end{array}$ & $\begin{array}{l}\text { Acid hydrolysis (fmol PhIP/ } \\
\text { pmol albumin) }\end{array}$ & $\begin{array}{l}\text { Pronase E digestion (fmol } \\
\text { PhIP/pmol albumin) }\end{array}$ \\
\hline PhIP & $88 \pm 0.8$ & $64 \pm 14.6$ & $1.3 \pm 0.1$ & $3.3 \pm 0.3$ \\
\hline
\end{tabular}




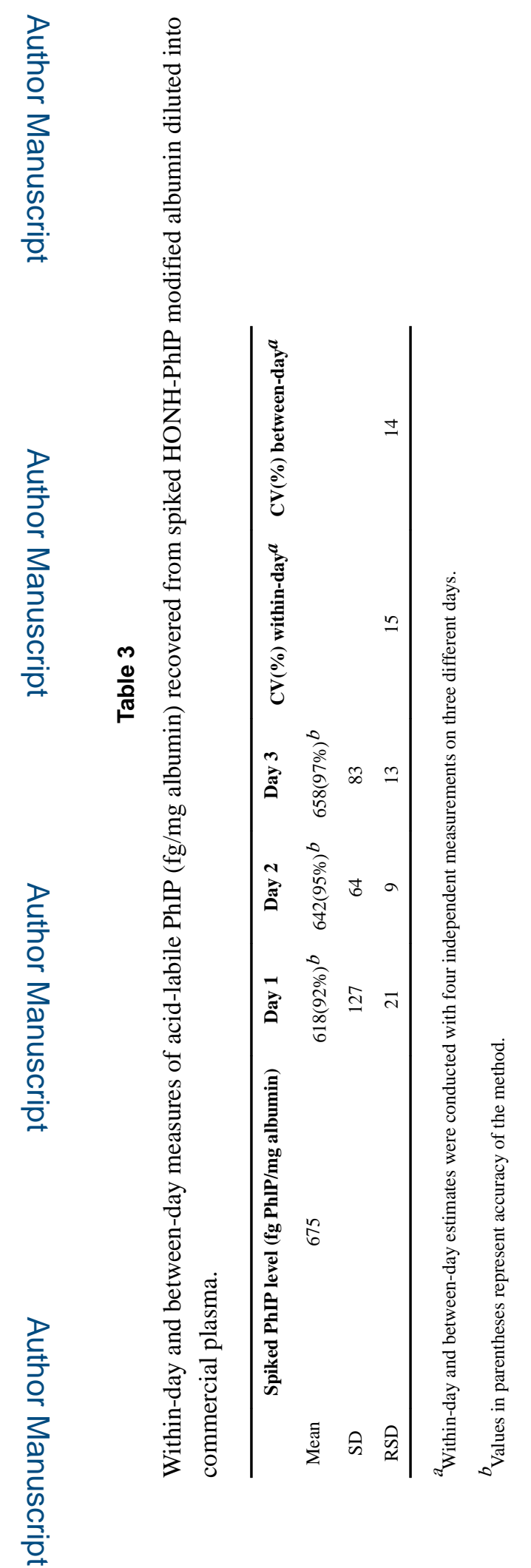

Chem Res Toxicol. Author manuscript; available in PMC 2018 February 20. 


\section{롤}

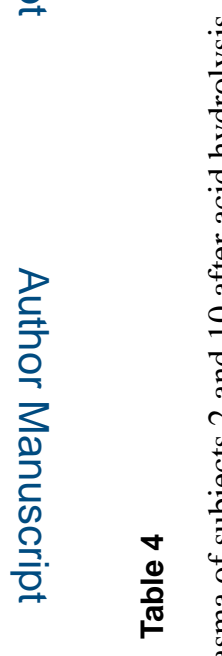

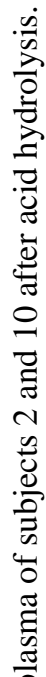

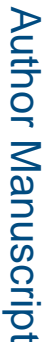

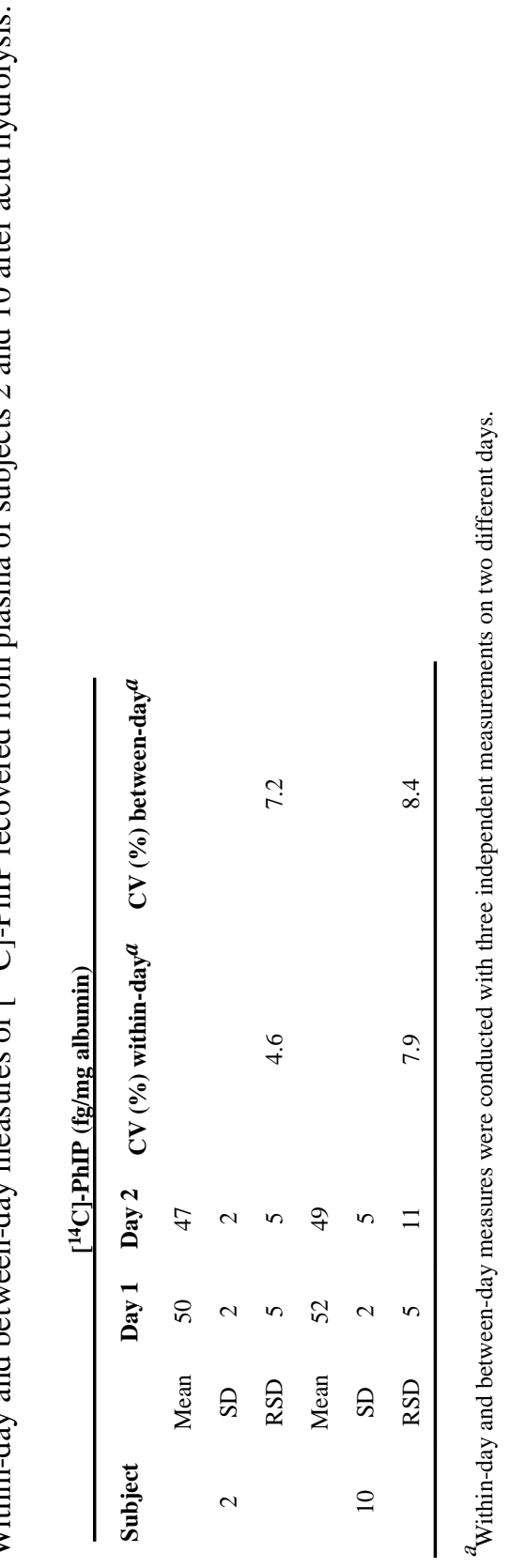

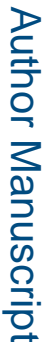




\section{Table 5}

An estimate of $\left[{ }^{14} \mathrm{C}\right]-\mathrm{PhIP}$-albumin adduct level from subjects administered $\left[{ }^{14} \mathrm{C}\right]-\mathrm{PhIP}$ in vivo ${ }^{a, b}$

UPLC/MS

Subject

Treatment
$1, \mathrm{~T}_{0}$

$1, \mathrm{~T}_{24}$

$1, \mathrm{~T}_{24}$

$2, \mathrm{~T}_{0}$

$2, \mathrm{~T}_{24}$

$2, \mathrm{~T}_{24}$

$7, \mathrm{~T}_{0}$

$7, \mathrm{~T}_{24}$

$10, \mathrm{~T}_{0}$

$10, \mathrm{~T}_{24}$
Acid hydrolysis or pronase E digestion

Acid hydrolysis

Pronase E digestion

Acid hydrolysis \& pronase E digestion

$$
\text { Acid hydrolysis }
$$

Pronase E digestion

Acid hydrolysis or pronase $\mathrm{E}$ digestion

Acid hydrolysis

Acid hydrolysis

Acid hydrolysis
Acid Labile $\left(\left[{ }^{14} \mathrm{C}\right]-\mathrm{PhIP}\right.$ fg/mg

albumin)

ND

$57 \pm 2$

$44 \pm 3$

ND

$49 \pm 3$

$38 \pm 3$

ND

$28 \pm 2$

ND

$51 \pm 4$
AMS

( $\left[{ }^{14} \mathrm{C}\right]$-PhlP bound fg/mg albumin)

$\%\left[{ }^{14} \mathrm{C}\right]-\mathrm{PhlP}$ bound recovered as $\left[{ }^{14} \mathrm{C}\right]-\mathrm{PhlP}$

$392 \pm 4$

14.5

$681 \pm 10$

7.2

${ }^{a}$ Albumin was purified from plasma at $\mathrm{T}_{0}$ or $\mathrm{T}_{24} \mathrm{~h}$ and treated with $0.1 \mathrm{~N} \mathrm{HCl}$ or pronase $\mathrm{E}$ digestion.

Values of acid-labile $\left[{ }^{14} \mathrm{C}\right]-\mathrm{PhIP}$ measured by UPLC/MS 3 are reported as the mean $\pm \mathrm{SD}(n=3)$. For subjects 1 and 2 , the AMS measurement values are the mean \pm SD of four independent analyses. The AMS analyses for subjects 7 and 10 are from single analyses $( \pm$ SD of the AMS measurement). ND, not detected, below the LOD.

${ }^{b}$ Albumin adduct data obtained by AMS represents the $\left[{ }^{14} \mathrm{C}\right]-\mathrm{PhIP}$ component of adduct levels and not unlabeled adducts. In the Dingley paper, ${ }^{24}$ the total adduct levels (labeled and unlabeled PhIP) were reported. 